\title{
Safety and Seroconversion of Immunotherapies against SARS-CoV-2 Infection: A Systematic Review and Meta-Analysis of Clinical Trials
}

\author{
Kevin Sheng-Kai Ma ${ }^{1,2,3,+} \mathbb{1}$, Chien-Chang Lee ${ }^{4,+}$, Ko-Jiunn Liu ${ }^{5}$, James Cheng-Chung Wei ${ }^{6}(\mathbb{D}$, \\ Yuan-Ti Lee ${ }^{7,8, *(D)}$ and Li-Tzu Wang ${ }^{9, *}$
}

check for updates

Citation: Ma, K.S.-K.; Lee, C.-C.; Liu, K.-J.; Wei, J.C.-C.; Lee, Y.-T.; Wang, L.-T. Safety and Seroconversion of Immunotherapies against SARS-CoV-2 Infection: A Systematic Review and Meta-Analysis of Clinical Trials. Pathogens 2021, 10, 1537. https://doi.org/10.3390/ pathogens 10121537

Academic Editors: Wenjun Ma and Alexander W.E. Franz

Received: 10 October 2021

Accepted: 19 November 2021

Published: 24 November 2021

Publisher's Note: MDPI stays neutral with regard to jurisdictional claims in published maps and institutional affiliations.

Copyright: (c) 2021 by the authors. Licensee MDPI, Basel, Switzerland. This article is an open access article distributed under the terms and conditions of the Creative Commons Attribution (CC BY) license (https:// creativecommons.org/licenses/by/ $4.0 /)$.
1 Center for Global Health, Perelman School of Medicine, University of Pennsylvania, Philadelphia, PA 19104, USA; kevinskma@hep1.phys.ntu.edu.tw

2 Graduate Institute of Biomedical Electronics and Bioinformatics, College of Electrical Engineering and Computer Science, National Taiwan University, Taipei 10617, Taiwan

3 Department of Dentistry, Chung Shan Medical University and Chung Shan Medical University Hospital, Taichung 40201, Taiwan

4 Department of Emergency Medicine, National Taiwan University Hospital, Taipei 10002, Taiwan; cclee100@gmail.com

5 National Institute of Cancer Research, National Health Research Institutes, Zhunan Township, Miaoli County 35053, Taiwan; kojiunn@nhri.edu.tw

6 Department of Allergy, Immunology and Rheumatology, Chung Shan Medical University Hospital, Taichung 40201, Taiwan; wei3228@gmail.com

7 School of Medicine, Chung Shan Medical University, Taichung 40201, Taiwan

8 Division of Infectious Diseases, Department of Internal Medicine, Chung Shan Medical University Hospital, Taichung 40201, Taiwan

9 Department of Obstetrics \& Gynecology, National Taiwan University Hospital \& College of Medicine, Taipei 10002, Taiwan

* Correspondence: leey521@gmail.com (Y.-T.L.); lizwang@ntu.edu.tw (L.-T.W.)

+ These authors have contributed equally to this work and share first authorship.

Abstract: Clinical trials evaluating the safety and antibody response of strategies to manipulate prophylactic and therapeutic immunity have been launched. We aim to evaluate strategies for augmentation of host immunity against severe acute respiratory syndrome coronavirus-2 (SARS-CoV2) infection. We searched clinical trials registered at the National Institutes of Health by 25 May 2021 and conducted analyses on inoculated populations, involved immunological processes, source of injected components, and trial phases. We then searched PubMed, Embase, Scopus, and the Cochrane Central Register of Controlled Trials for their corresponding reports published by 25 May 2021. A bivariate, random-effects meta-analysis was used to derive the pooled estimate of seroconversion and adverse events (AEs). A total of 929,359 participants were enrolled in 389 identified trials. The working mechanisms included heterologous immunity, active immunity, passive immunity, and immunotherapy, with $62.4 \%$ of the trials on vaccines. A total of 9072 healthy adults from 27 publications for 22 clinical trials on active immunity implementing vaccination were included for meta-analyses. The pooled odds ratios (ORs) of seroconversion were 13.94, 84.86, 106.03, and 451.04 (all $p<0.01$ ) for vaccines based on protein, RNA, viral vector, and inactivated virus, compared with that of respective placebo/control treatment or pre-vaccination sera. The pooled ORs for safety, as defined by the inverse of systemic adverse events (AEs) were $0.53(95 \% \mathrm{CI}=0.27-1.05 ; p=0.07), 0.35$ (95\% CI $=0.16-0.75 ; p=0.007), 0.32(95 \% \mathrm{CI}=0.19-0.55 ; p<0.0001)$, and 1.00 (95\% CI = 0.73-1.36; $p=0.98$ ) for vaccines based on protein, RNA, viral vector, and inactivated virus, compared with that of placebo/control treatment. A paradigm shift from all four immune-augmentative interventions to active immunity implementing vaccination was observed through clinical trials. The efficacy of immune responses to neutralize SARS-CoV-2 for these vaccines was promising, although systemic AEs were still evident for RNA-based and viral vector-based vaccines.

Keywords: coronavirus disease 2019 (COVID-19); severe acute respiratory syndrome coronavirus 2 (SARS-CoV-2); heterologous immunity; active immunity; passive immunity 


\section{Introduction}

Coronavirus disease 2019 (COVID-19), caused by the corresponding pathogen severe acute respiratory syndrome coronavirus 2 (SARS-CoV-2), has rapidly threatened global health and economic systems [1,2]. Belonging to the Coronaviridae family, SARS-CoV-2 contains a positive single-strand RNA genome of 29.8 to $29.9 \mathrm{~kb}$, which encodes two replicase/transcriptase ORF1ab and six accessory proteins, as well as four structural proteins, including nucleocapsid $(\mathrm{N})$, envelop $(\mathrm{E})$, membrane $(\mathrm{M})$ and spike $(\mathrm{S})$ proteins, with the last being the protein crucial to infecting target cells via binding to the angiotensinconverting enzyme II (ACE2) [3]. As a highly contagious virus, transmission sources of SARS-CoV-2 include discharge or direct contact with droplets and fomites that contain virus particles through the mouth, nose, or eyes. As of 25 May 2021, according to the Johns Hopkins Centers for Civic Impact [4], there were 170,354,142 confirmed cases and 3,541,800 deaths, with a mortality rate of $2.08 \%$. Among all registered regions, the United States had the most cases of COVID-19, with 33,200,765 confirmed cases and 593,419 deaths. To date, rising numbers of clinical trials on the safety and antibody response of strategies to manipulate prophylactic and therapeutic immunity have been launched.

Host immunity is one of the most effective defense mechanisms against severely infectious diseases through comprehensive regulations in the immune system. If COVID-19 is to be effectively controlled, the most pivotal measure would be the development of effective immunity via vaccination or direct transfer of immunity for prophylactic or therapeutic purposes. Generally, three pathways of immunity induction are classified: vaccination to induce heterologous immunity or active immunity, transfer of active humoral immunity, which is also called passive immunity, and direct manipulation of immunity known as immunotherapy [5]. Among them, heterologous immunity refers to the induction of crossprotection by training innate immunity via vaccination of irrelevant pathogens [6]. On the other hand, active immunity triggers adaptive immune responses that involve both cellular and humoral responses with vaccine-induced immunological memory, while passive immunity utilizes antibodies against pathogen spreading and infection [7]. Immunotherapy is originally designed for the treatment of cancer by enhancement of anti-tumor immune activity via transfer of immune activator/cells or blockage of suppressor signals, such as programmed cell death protein-1 (PD-1)/PD-L1 pathway [8].

The holy grail that numerous clinicians and scientists are striving for during the COVID-19 crisis has been the successful vaccine or direct transfer of protective immunity. The purpose of this article is therefore to introduce and discuss these ongoing clinical trials registered at the National Institutes of Health (NIH) (ClinicalTrials.gov) for a systemic review and perform a meta-analysis on safety and antibody response for published results from current trials.

\section{Results}

\subsection{Systematic Review of Clinical Trials}

As of 25 May 2021, we appraised 389 registered clinical trials for COVID-19 based on non-pharmaceutical interventions (NPIS) for augmenting immunity, specifically vaccination or immunotherapy. A total of 929,359 healthy adults population susceptible to SARS-CoV-2 infection or patients with COVID-19 were enrolled in those clinical trials. Moreover, increasing numbers of registered trials aimed at inducing active immunity were observed in more current months (Figure 1). According to their working mechanisms, the 389 clinical trials may be classified into vaccination for induction of heterologous or active immunity, immunoglobulin transfer for providing passive immunity, and immunotherapy (Table 1, trial numbers; Table 2, participant numbers). 


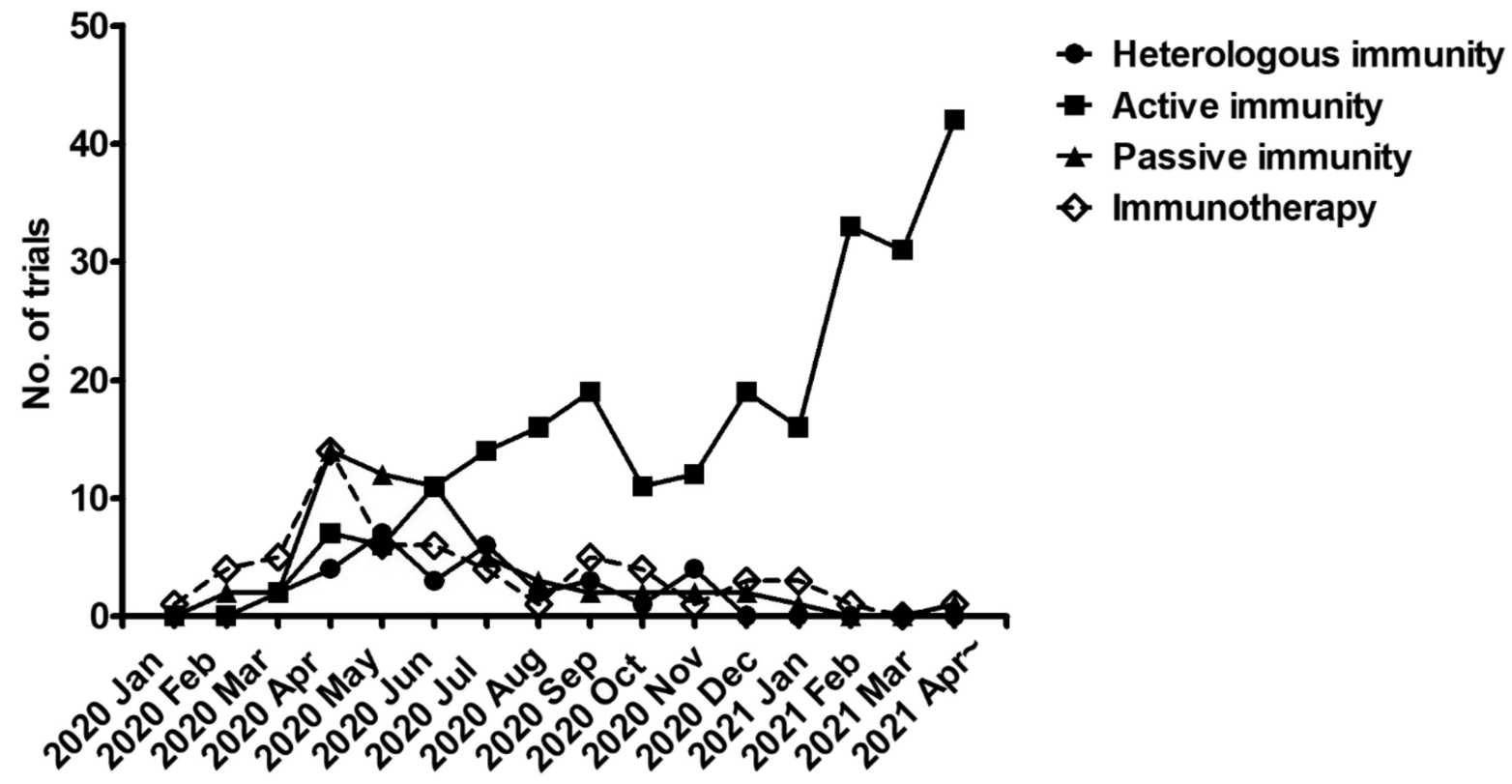

Figure 1. Accumulated numbers of clinical trials on prevention or therapy of COVID-19 via immunity augmentation by time-course analyses.

Table 1. Distribution of clinical trials on immunity augmentation for COVID-19.

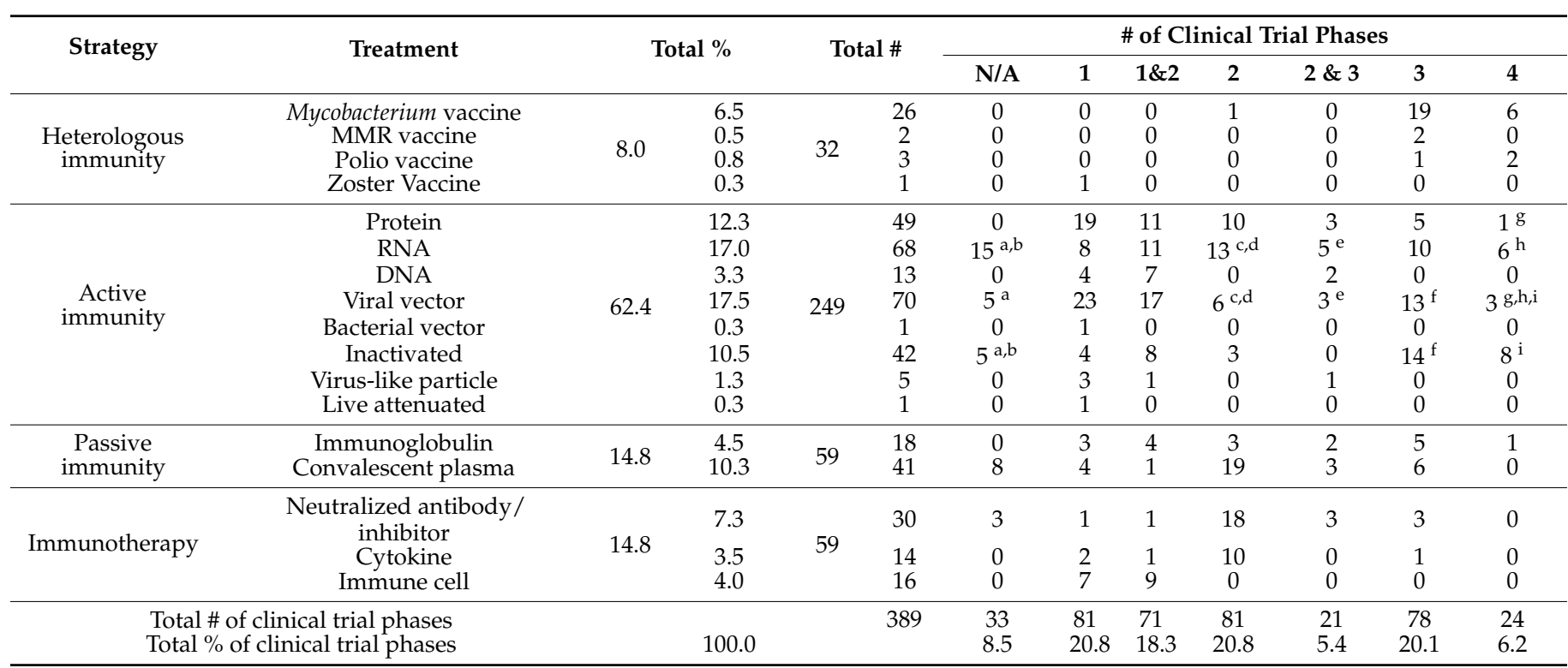

$\mathrm{a}, \mathrm{b}, \mathrm{c}, \mathrm{d}, \mathrm{e}, \mathrm{f}, \mathrm{g}, \mathrm{h}, \mathrm{i}$ Strategies of active immunity are applied to the same clinical trials.

\subsubsection{Cross-Protective Vaccines Realizing Heterologous Immunity}

Although they do not directly target SARS-CoV-2, the off-label use of Mycobacterium (phase 3: $n=19$, participants $=29,202$; phase 4: $n=6$, participants $=10,864$ ), measles mumps and rubella (MMR, phase 3: $n=2$, participants $=260$ ), poliovirus (phase 3: $n=$ 1 , participants $=3600$; phase 4: $n=2$, participants $=3425$ ), and Zoster (phase 1: $n=1$, participants $=250$ ) vaccines have been rapidly authorized for clinical trials due to their well-established safety and potential to induce heterologous immunity. Among 26 trials using Mycobacterium vaccines, 20 of them used BCG, including 19 for prevention and one for therapy (trial number NCT04369794), in which humoral response against SARS-CoV-2 for the elimination of symptoms in patients with COVID-19. To determine whether BCG vaccination may prevent COVID-19 progression, we analyzed epidemiological data of 
reported COVID-19 cases by 12 September 2020, which was commonly used as a substitute when vaccination was not popularized. The retrieved data were from high-income countries whose claimed healthcare data on the BCG World Atlas [9] were considered reflective of the larger population (Supplementary Table S1). Although the incidence rate of COVID-19 was not different in countries with versus without BCG vaccination policy (Supplementary Figure S1A), the average mortality rate was significantly lower in countries implementing BCG vaccination policy $(2.17 \%$, ranging from $0 \%$ to $5.83 \%)$ than that of countries without such policy (5.1\%, ranging from $0.73 \%$ to $12.56 \%$ ) (Supplementary Figure S1B), suggesting the efficacy of BCG-mediated training or heterologous immunity for fir alleviating complications of COVID-19. Our cross-sectional analyses revealed significant differences in mortality for COVID-19 among countries with and without current $B C G$ vaccination policies, indicating the protective role of BCG immunization on the induction of heterologous immunity against SARS-CoV-2. During the pandemic, off-label use of vaccines such as BCG and MMR vaccines [10] have been repurposed in the hope of establishing heterologous immunity against SARS-CoV-2 and have been provided to individuals with high-risk occupations for COVID-19, including healthcare providers.

Table 2. Distribution of enrolled participants in clinical trials on immunity augmentation for COVID-19.

\begin{tabular}{|c|c|c|c|c|c|c|c|c|c|c|}
\hline \multirow{2}{*}{ Strategy } & \multirow{2}{*}{ Treatment } & \multirow{2}{*}{\multicolumn{2}{|c|}{ Total \# }} & \multicolumn{7}{|c|}{ \# of Participants in Clinical Trial Phases } \\
\hline & & & & N/A & 1 & $1 \& 2$ & 2 & $2 \& 3$ & 3 & 4 \\
\hline \multirow{2}{*}{$\begin{array}{l}\text { Heterologous } \\
\text { immunity }\end{array}$} & $\begin{array}{l}\text { Mycobacterium } \\
\text { vaccine }\end{array}$ & \multirow{2}{*}{48,601} & 41,066 & 0 & 0 & 0 & 1000 & 0 & 29,202 & 10,864 \\
\hline & $\begin{array}{l}\text { MMR vaccine } \\
\text { Polio vaccine } \\
\text { Zoster Vaccine }\end{array}$ & & $\begin{array}{c}260 \\
7025 \\
250\end{array}$ & $\begin{array}{l}0 \\
0 \\
0\end{array}$ & $\begin{array}{c}0 \\
0 \\
250\end{array}$ & $\begin{array}{l}0 \\
0 \\
0\end{array}$ & $\begin{array}{l}0 \\
0\end{array}$ & $\begin{array}{l}0 \\
0 \\
0\end{array}$ & $\begin{array}{c}260 \\
3600 \\
0\end{array}$ & $\begin{array}{c}0 \\
3425 \\
0\end{array}$ \\
\hline $\begin{array}{l}\text { Active } \\
\text { immunity }\end{array}$ & $\begin{array}{c}\text { Protein } \\
\text { RNA } \\
\text { DNA } \\
\text { Viral vector } \\
\text { Bacterial vector } \\
\text { Inactivated/LVP } \\
\text { Live attenuated }\end{array}$ & 878,370 & $\begin{array}{c}172,672 \\
162,052 \\
8481 \\
271,524 \\
84 \\
263,949 \\
48\end{array}$ & $\begin{array}{c}0 \\
9502^{a, b} \\
0 \\
3770^{a} \\
0 \\
2461^{a, b} \\
0\end{array}$ & $\begin{array}{c}1616 \\
981 \\
298 \\
2688 \\
84 \\
570 \\
48 \\
\end{array}$ & $\begin{array}{c}6600 \\
13,961 \\
1105 \\
9025 \\
0 \\
5300 \\
0\end{array}$ & $\begin{array}{c}18,016 \\
6708^{\mathrm{c}, \mathrm{d}} \\
0 \\
3691^{\mathrm{c}, \mathrm{d}} \\
0 \\
1750 \\
0\end{array}$ & $\begin{array}{c}29,320 \\
54,550^{\mathrm{e}} \\
7078 \\
17,930^{\mathrm{e}} \\
0 \\
30,612 \\
0\end{array}$ & $\begin{array}{c}117,000 \\
65,500 \\
0 \\
224,000^{\mathrm{f}} \\
0 \\
175,790^{\mathrm{f}} \\
0\end{array}$ & $\begin{array}{c}120^{\mathrm{g}} \\
10,850^{\mathrm{h}} \\
0 \\
10,420^{\mathrm{g}, \mathrm{h}, \mathrm{i}} \\
0 \\
47,466^{\mathrm{i}} \\
0\end{array}$ \\
\hline $\begin{array}{l}\text { Passive } \\
\text { immunity }\end{array}$ & $\begin{array}{l}\text { Immunoglobulin } \\
\text { Convalescent plasma }\end{array}$ & 16,620 & $\begin{array}{c}2756 \\
13,864\end{array}$ & $\begin{array}{c}0 \\
6424\end{array}$ & $\begin{array}{c}74 \\
150\end{array}$ & $\begin{array}{l}239 \\
15\end{array}$ & $\begin{array}{c}226 \\
2527\end{array}$ & $\begin{array}{l}390 \\
688\end{array}$ & $\begin{array}{l}1787 \\
4060\end{array}$ & $\begin{array}{c}40 \\
0\end{array}$ \\
\hline Immunotherapy & $\begin{array}{l}\text { Neutralized } \\
\text { antibody/ } \\
\text { inhibitor } \\
\text { Cytokine } \\
\text { Immune cell }\end{array}$ & 6988 & $\begin{array}{l}3547 \\
2329 \\
1112\end{array}$ & $\begin{array}{c}204 \\
\\
0 \\
0\end{array}$ & $\begin{array}{c}50 \\
82 \\
280\end{array}$ & $\begin{array}{c}18 \\
\\
80 \\
832\end{array}$ & $\begin{array}{c}2409 \\
1129 \\
0\end{array}$ & $\begin{array}{c}320 \\
0 \\
0\end{array}$ & $\begin{array}{c}546 \\
1038 \\
0\end{array}$ & $\begin{array}{l}0 \\
0 \\
0\end{array}$ \\
\hline Total partic & pants in clinical trial ph & & 929,359 & 22,761 & 7171 & 37,175 & 34,816 & 136,888 & 618,783 & 72,765 \\
\hline
\end{tabular}

Participant \# in the same clinical trials: ${ }^{\mathrm{a}} 100,{ }^{\mathrm{b}} 400,{ }^{\mathrm{c}} 900,{ }^{\mathrm{d}} 1300, \mathrm{e} 4000,{ }^{\mathrm{f}} 4000,{ }^{\mathrm{g}} 120,{ }^{\mathrm{h}} 10,000,{ }^{\mathrm{i}} 300$.

\subsubsection{Inactivated and Subunit Vaccines Allowing for Active Immunity}

Vaccination, as a process, could also induce active immunity or immunological memory, followed by a prophylactic effect on specific pathogens. Those defending the infected individuals through such a mechanism include killed or inactivated, toxoid, subunit, and live-attenuated vaccines. Among them, trials of killed or inactivated, and subunit vaccines against COVID-19 are still in early phases due to safety concerns. Trials aiming at inducing active immunity in healthy individuals include inactivated virus vaccines including inactivated virus $(n=42$, total participants $=232,899)$ and S protein-derived subunit vaccines such as recombinant $S$ protein vaccines $(n=49$, participants $=172,232)$, mRNA vaccines $(n=68$, total participants $=162,052)$, DNA vaccines $(n=13$, participants $=$ $8481)$, viral vector-based vaccines $(n=70$, participants $=271,524)$, virus-like particles $(n=5$, participants $=31,050)$, and live recombinant bacterial vectors $(n=1$, participants $=84)$. Moreover, one of these trials evaluated the safety and antibody response of live-attenuated SARS-CoV-2 vaccines (participants $=48$ ).

\subsubsection{Convalescent Plasma or Immunoglobulin Transfer Providing Passive Immunity}

Among these trials aiming at transferring passive immunity, 18 trials administered intravenous immunoglobulin (participants $=2756$ ), and 41 trials implemented convalescent 
plasma (participants $=13,864$ ). In particular, 11 trials were in phase 3 , and 1 trial was in phase 4 , all of which revealed the therapeutic potential of immediate transfer of humoral immunity in COVID-19 patients.

\subsubsection{Immunotherapy}

Immune checkpoint inhibitors such as PD-1 inhibitors and neutralizing antibodies have been widely used as immunotherapy agents [11]. Overreaction of the immune system has been reported to drive severe COVID-19 disease progression [12]. There were 29 trials (total participants $=3547$ ) that evaluated immune checkpoint inhibitors including anti-PD-1 inhibitors such as nivolumab, anti-component 5a receptor (C5aR) monoclonal antibodies such as avdoralimab, and anti-IL6R neutralizing antibodies such as tocilizumab. Specifically, nivolumab was used to alleviate (cytotoxic T) $\mathrm{T}$ cell exhaustion that arose during SARS-CoV-2 infections [13], whereas avdoralimab and tocilizumab were expected to blockC5a/C5aR and IL6-IL6R pathways, which could bring about protective adaptive immunity [14] and block exuberant inflammation in COVID-19 pathogenesis [15]. On the other hand, immunotherapies aimed at increasing virus-eliminating immune pathways via the transfer of protective cytokines have been proposed. There were 14 trials (participants = 2329) that used cytokines such as IL-2 and IL-7 for lymphocyte activation [16] or type I IFNs to induce innate immunity against virus infections [17]. Ongoing trials on immune cell transfer $(n=16$, participants $=1112)$ include the transplantation of lentivirus-modified DCs, antigen-loaded DCs, allogeneic natural killer (NK) cells, NK cells modified by CAR (NKG2D-ACE2 CAR-NK Cells), all of which were of phase 1 or $1 \& 2$, aiming at evaluating safety performance.

\subsection{Meta-Analysis of Trial Reports}

There were 9072 participants among the 27 studies included in the meta-analysis (Table 3). AEs in all studies were evaluated. The time from designated intervention to venipuncture for seroconversion was restricted within 28 days post-vaccination to verify that the immune response was rapid and specifically against the SARS-CoV-2 virus. The key characteristics and details of all included studies were described in Supplementary Table S2.

Table 3. Characteristics of included studies.

\begin{tabular}{|c|c|c|c|c|c|c|c|}
\hline Type & $\begin{array}{c}\text { Authors } \\
\text { (Journal \& Year) }\end{array}$ & NCT Number & Phase & Participants & Vaccination Procedures & $\begin{array}{l}\text { Outcome Measures on Safety } \\
\text { and Immunogenicity }\end{array}$ & Storage \\
\hline \multirow{5}{*}{ Protein } & $\begin{array}{c}\text { Keech et al. (N } \\
\text { Engl J Med 2020) } \\
{[18]}\end{array}$ & 04368988 & 1 & 131 & $\begin{array}{c}\text { Intramuscular injections of } \\
\text { NVX-CoV2373 }(5,25 \mu \mathrm{g}) \text { at } \\
\text { day } 0 \text { or/and } 21\end{array}$ & $\begin{array}{l}\text { Local, systemic, and unsolicited } \\
\text { AEs; anti-S antibody; } \\
\text { SARS-CoV-2-neutralizing } \\
\text { antibody }\end{array}$ & $2-8{ }^{\circ} \mathrm{C}$ \\
\hline & $\begin{array}{c}\text { Richmond et al. } \\
\text { (Lancet 2021) } \\
\text { [19] }\end{array}$ & 04405908 & 1 & 151 & $\begin{array}{c}\text { Intramuscular injections of } \\
\text { SCB-2019 }(3,9 \text {, or } 30 \mu \mathrm{g}) \text { at } \\
\text { days } 0 \text { and } 21\end{array}$ & $\begin{array}{c}\text { Local and systemic AEs; } \\
\text { anti-SCB-2019 antibody; } \\
\text { SARS-CoV-2-neutralizing } \\
\text { antibody }\end{array}$ & $2-8^{\circ} \mathrm{C}$ \\
\hline & $\begin{array}{l}\text { Yang et al. } \\
\text { (Lancet Infect } \\
\text { Dis 2021) [20] }\end{array}$ & $\begin{array}{l}04445194 \& \\
04466085\end{array}$ & $1 \& 2$ & 950 & $\begin{array}{c}\text { Intramuscular injections of } \\
\text { ZF2001 at day 0, 30, } 60 \text { for } \\
\text { phase } 1 \text { trial, and at day } 0,30 \\
\text { or day } 0,30,60 \text { for phase } 2 \\
\text { trial }\end{array}$ & $\begin{array}{l}\text { Local, systemic, and unsolicited } \\
\text { AEs; anti-RBD antibody; } \\
\text { SARS-CoV-2-neutralizing } \\
\text { antibody }\end{array}$ & $2-8{ }^{\circ} \mathrm{C}$ \\
\hline & $\begin{array}{c}\text { Chappell (Lancet } \\
\text { Infect Dis 2021) } \\
{[21]}\end{array}$ & 04495933 & 1 & 120 & $\begin{array}{c}\text { Intramuscular injections of } \\
\text { S-clamp vaccine }(5,15, \text { or } 45 \\
\mu \mathrm{g}) \text { at days } 0 \text { and } 28\end{array}$ & $\begin{array}{l}\text { Local, systemic, and unsolicited } \\
\text { AEs; Anti-clamp antibody; } \\
\text { SARS-CoV-2-neutralizing } \\
\text { antibody }\end{array}$ & $2-8^{\circ} \mathrm{C}$ \\
\hline & $\begin{array}{l}\text { Goepfert et al. } \\
\text { (Lancet Infect } \\
\text { Dis 2021) [22] }\end{array}$ & 04537208 & $1 \& 2$ & 441 & $\begin{array}{l}\text { Intramuscular injections of } \\
\mathrm{CoV} 2 \text { preS dTM ( } 1.3 \text { or } 2.6 \\
\mu \mathrm{g} \text { ) at day } 1 \text { for one dose or } \\
\text { day } 1 \text { and } 28 \text { for two doses }\end{array}$ & $\begin{array}{l}\text { Local, systemic, and unsolicited } \\
\text { AEs; SARS-CoV-2-neutralizing } \\
\text { antibody }\end{array}$ & $2-8^{\circ} \mathrm{C}$ \\
\hline
\end{tabular}


Table 3. Cont.

\begin{tabular}{|c|c|c|c|c|c|c|c|}
\hline Type & $\begin{array}{c}\text { Authors } \\
\text { (Journal \& Year) }\end{array}$ & NCT Number & Phase & Participants & Vaccination Procedures & $\begin{array}{l}\text { Outcome Measures on Safety } \\
\text { and Immunogenicity }\end{array}$ & Storage \\
\hline \multirow{6}{*}{ RNA } & $\begin{array}{l}\text { Anderson et al. } \\
\text { (N Engl J Med } \\
\text { 2020) [23] }\end{array}$ & 04283461 & 1 & 40 & $\begin{array}{c}\text { Intramuscular injections of } \\
\text { mRNA-1273 }(25 \text { or } 100 \mu \mathrm{g}) \text { at } \\
\text { days } 1 \text { and } 29\end{array}$ & $\begin{array}{l}\text { Local and systemic AEs; } \\
\text { anti-S-2P antibody; anti-RBD } \\
\text { antibody; SARS-CoV-2 } \\
\text { neutralizing antibody }\end{array}$ & $\begin{array}{l}-20^{\circ} \mathrm{C} \text { or } \\
2-8{ }^{\circ} \mathrm{C}\end{array}$ \\
\hline & $\begin{array}{c}\text { Chu et al. } \\
\text { (Vaccine 2021) } \\
\text { [24] }\end{array}$ & 04405076 & 2 & 600 & $\begin{array}{c}\text { Intramuscular injections of } \\
\text { mRNA-1273 (50 or } 100 \mu \mathrm{g}) \text { at } \\
\text { days } 1 \text { and } 29\end{array}$ & $\begin{array}{l}\text { Local and systemic AEs; Anti-S } \\
\text { antibody; } \\
\text { SARS-CoV-2-neutralizing } \\
\text { antibody }\end{array}$ & $\begin{array}{l}-20^{\circ} \mathrm{C} \text { or } \\
2-8{ }^{\circ} \mathrm{C}\end{array}$ \\
\hline & $\begin{array}{l}\text { Jackson et al. (N } \\
\text { Engl J Med 2020) } \\
\text { [25] }\end{array}$ & 04283461 & 2 & 45 & $\begin{array}{l}\text { Intramuscular injections of } \\
\text { mRNA- } 1273(25,100,250 \mu \mathrm{g}) \\
\text { at days } 1 \text { and } 29\end{array}$ & $\begin{array}{c}\text { Local, systemic, and unsolicited } \\
\text { AEs; anti-S-2P antibody; } \\
\text { anti-RBD antibody; } \\
\text { SARS-CoV-2-neutralizing } \\
\text { antibody }\end{array}$ & $\begin{array}{l}-20^{\circ} \mathrm{C} \text { or } \\
2-8{ }^{\circ} \mathrm{C}\end{array}$ \\
\hline & $\begin{array}{l}\text { Mulligan et al. } \\
\text { (Nature 2020) } \\
{[26]}\end{array}$ & 04368728 & $1 \& 2$ & 45 & $\begin{array}{c}\text { Intramuscular injection of } \\
\text { BNT162b1 (10, } 30 \mu \mathrm{g}) \text { at day } 0 \\
\text { and } 21 \text { or BNT162b1 (100 } \mu \mathrm{g}) \\
\text { at day0 }\end{array}$ & $\begin{array}{l}\text { Local and systemic AEs; } \\
\text { anti-RBD antibody; } \\
\text { SARS-CoV-2-neutralizing } \\
\text { antibody }\end{array}$ & $-80^{\circ} \mathrm{C}$ \\
\hline & $\begin{array}{c}\text { Sahin et al. } \\
\text { (Nature 2020) } \\
\text { [27] }\end{array}$ & 04368728 & $1 \& 2$ & 60 & $\begin{array}{c}\text { Intramuscular injections of } \\
\text { BNT162b1 }(1,10,30,50 \mu \mathrm{g}) \text { at } \\
\text { day } 1 \text { and } 22 \text { or BNT162b1 (60 } \\
\mu \mathrm{g}) \text { at day } 1\end{array}$ & $\begin{array}{l}\text { Local and systemic AEs; } \\
\text { anti-RBD antibody; } \\
\text { SARS-CoV-2-neutralizing } \\
\text { antibody }\end{array}$ & $-80^{\circ} \mathrm{C}$ \\
\hline & $\begin{array}{l}\text { Walsh et al. (N } \\
\text { Engl J Med 2020) } \\
\text { [28] }\end{array}$ & 04368728 & $1 \& 2$ & 195 & $\begin{array}{l}\text { Intramuscular injections of } \\
\text { BNT162b1 or BNT162b2 (10, } \\
20,30 \mu \mathrm{g}) \text { at day } 0 \text { and } 21\end{array}$ & $\begin{array}{l}\text { Local and systemic AEs; anti-S1 } \\
\text { antibody; } \\
\text { SARS-CoV-2-neutralizing } \\
\text { antibody }\end{array}$ & $-80^{\circ} \mathrm{C}$ \\
\hline DNA & $\begin{array}{l}\text { Tebas et al. } \\
\text { (EClini- } \\
\text { calMedicine } \\
\text { 2021) [29] }\end{array}$ & 04336410 & 1 & 40 & $\begin{array}{c}\text { Intrdermal injections of } \\
\text { INO-4800 (1, } 2 \mathrm{mg}) \text { at weeks } 0 \\
\text { and } 4\end{array}$ & $\begin{array}{l}\text { Local and systemic AEs; anti-S } \\
\text { antibody; } \\
\text { SARS-CoV-2-neutralizing } \\
\text { antibody }\end{array}$ & $2-8^{\circ} \mathrm{C}$ \\
\hline \multirow{8}{*}{ Viral vector } & $\begin{array}{c}\text { Zhu et al. } \\
\text { (Lancet 2020a) } \\
\text { [30] }\end{array}$ & 04313127 & 1 & 108 & $\begin{array}{l}\text { Intramuscular injection of } \\
\text { adenovirus type- } 5 \text { vectored } \\
\text { COVID-19 vaccine }\left(5 \times 10^{10}, 1\right. \\
\times 10^{11} \text {, and } 1.5 \times 10^{11} \text { viral } \\
\text { particles) at day } 0\end{array}$ & $\begin{array}{l}\text { Local and systemic AEs; } \\
\text { anti-RBD antibody; SARS-CoV-2 } \\
\text { neutralizing antibody }\end{array}$ & $\mathrm{N} / \mathrm{A}$ \\
\hline & $\begin{array}{c}\text { Folegatti et al. } \\
\text { (Lancet 2020) } \\
\text { [31] }\end{array}$ & 04324606 & $1 \& 2$ & 1077 & $\begin{array}{l}\text { Intramuscular injections of } \\
\text { AZD1222 }\left(5 \times 10^{10} \text { viral }\right. \\
\text { particles }) \text { at days } 0 \text { and } 28\end{array}$ & $\begin{array}{l}\text { Local, systemic, and unsolicited } \\
\text { AEs; anti-Spike antibody; } \\
\text { SARS-CoV-2 neutralizing } \\
\text { antibody }\end{array}$ & $\begin{array}{l}-80^{\circ} \mathrm{C} \text { or } \\
2-8 \mathrm{~K} 22\end{array}$ \\
\hline & $\begin{array}{l}\text { Barrett et al. (Nat } \\
\text { Med 2021) [32] }\end{array}$ & 04324606 & $1 \& 2$ & 52 & $\begin{array}{c}\text { Intramuscular injections of } \\
\text { AZD1222 }\left(5 \times 10^{9} \text { or } 2.5 \times\right. \\
\left.10^{10} \text { viral particles }\right) \text { at days } 0 \\
\text { and } 28\end{array}$ & $\begin{array}{l}\text { Local and systemic AEs; anti-S } \\
\text { antibody; anti-RBD antibody; } \\
\text { SARS-CoV-2-neutralizing } \\
\text { antibody }\end{array}$ & $\begin{array}{l}-80^{\circ} \mathrm{C} \text { or } \\
2-8{ }^{\circ} \mathrm{C}\end{array}$ \\
\hline & $\begin{array}{c}\text { Zhu et al. } \\
\text { (Lancet 2020b) } \\
\text { [33] }\end{array}$ & 04341389 & 2 & 508 & $\begin{array}{c}\text { Intramuscular injection of } \\
\text { adenovirus type- } 5 \text { vectored } \\
\text { COVID-19 vaccine }\left(5 \times 10^{10}\right. \\
\left.\text { or } 1 \times 10^{11} \text { viral particles }\right) \text { at } \\
\text { day } 0\end{array}$ & $\begin{array}{c}\text { Local, systemic, and unsolicited } \\
\text { AEs; anti-RBD antibody; } \\
\text { SARS-CoV-2-neutralizing } \\
\text { antibody }\end{array}$ & $\mathrm{N} / \mathrm{A}$ \\
\hline & $\begin{array}{c}\text { Ramasamy et al. } \\
\text { (Lancet 2021) } \\
\text { [34] }\end{array}$ & 04400838 & $2 \& 3$ & 560 & $\begin{array}{c}\text { Intramuscular injections of } \\
\text { AZD1222 }\left(2.2 \times 10^{10} \text { or }\right. \\
\left.3.5-6.5 \times 10^{10} \text { viral particles }\right) \\
\text { at days } 0 \text { and } 28\end{array}$ & $\begin{array}{l}\text { Local and systemic AEs; anti-S } \\
\text { antibody; anti-RBD antibody; } \\
\text { SARS-CoV-2-neutralizing } \\
\text { antibody }\end{array}$ & $\begin{array}{l}-80^{\circ} \mathrm{C} \text { or } \\
2-8{ }^{\circ} \mathrm{C}\end{array}$ \\
\hline & $\begin{array}{c}\text { Sadoff et al. (N } \\
\text { Engl J Med 2021) } \\
\text { [35] }\end{array}$ & 04436276 & $1 \& 2$ & 805 & $\begin{array}{c}\text { Intramuscular injections of } \\
\text { Ad26.COV2.S }\left(5 \times 10^{10} \text { or } 1 \times\right. \\
10^{11} \text { viral particles) at day } 1 \\
\text { or } / \text { and day } 57\end{array}$ & $\begin{array}{l}\text { Local, systemic, and severe } \\
\text { unsolicited AEs; Anti-S antibody; } \\
\text { SARS-CoV-2-neutralizing } \\
\text { antibody }\end{array}$ & $2-8^{\circ} \mathrm{C}$ \\
\hline & $\begin{array}{l}\text { Stephenson et al. } \\
\text { (JAMA 2021) [36] }\end{array}$ & 04436276 & 1 & 25 & $\begin{array}{c}\text { Intramuscular injections of } \\
\text { Ad26.COV2.S }\left(5 \times 10^{10} \text { or } 1 \times\right. \\
10^{11} \text { viral particles) at day } 1 \\
\text { or/and day } 57\end{array}$ & $\begin{array}{l}\text { Local, systemic, and unsolicited } \\
\text { AEs; Anti-S antibody; Anti-RBD } \\
\text { antibody } \\
\text { SARS-CoV-2-neutralizing } \\
\text { antibody }\end{array}$ & $2-8^{\circ} \mathrm{C}$ \\
\hline & $\begin{array}{c}\text { Logunov et al. } \\
\text { (Lancet 2020) } \\
\text { [37] }\end{array}$ & $\begin{array}{c}04436471 \& \\
04437875\end{array}$ & $1 \& 2$ & 76 & $\begin{array}{l}\text { Intramuscular injections of } \\
\text { rAd26-S and rAd5-S at day } 0 \\
\text { for phase } 1 \text { trial, and at day } 0 \\
\text { and } 21 \text { for phase } 2 \text { trial }\end{array}$ & $\begin{array}{c}\text { Local and systemic AEs; } \\
\text { anti-RBD antibody; } \\
\text { SARS-CoV-2-neutralizing } \\
\text { antibody }\end{array}$ & $\begin{array}{c}\text { Frozen: }-18 \\
{ }^{\circ} \mathrm{C} \& \\
\text { lyophilized: } \\
2-8{ }^{\circ} \mathrm{C}\end{array}$ \\
\hline
\end{tabular}


Table 3. Cont.

\begin{tabular}{|c|c|c|c|c|c|c|c|}
\hline Type & $\begin{array}{c}\text { Authors } \\
\text { (Journal \& Year) }\end{array}$ & NCT Number & Phase & Participants & Vaccination Procedures & $\begin{array}{c}\text { Outcome Measures on Safety } \\
\text { and Immunogenicity }\end{array}$ & Storage \\
\hline \multirow{6}{*}{$\begin{array}{l}\text { Inactivated } \\
\quad \text { virus }\end{array}$} & $\begin{array}{l}\text { Zhang et al. } \\
\text { (Lancet Infect } \\
\text { Dis 2021) [38] }\end{array}$ & 04352608 & $1 \& 2$ & 744 & $\begin{array}{c}\text { Intramuscular injections of } \\
\text { CoronaVac }(3 \text { or } 6 \mu \mathrm{g}) \text { at day } \\
0 \text { and } 14 \text { or } 28 \text { for phase } 1 \text { or } \\
\text { phase } 2\end{array}$ & $\begin{array}{c}\text { Local, systemic, and unsolicited } \\
\text { AEs; Anti-RBD antibody; } \\
\text { SARS-CoV-2-neutralizing } \\
\text { antibody }\end{array}$ & $2-8^{\circ} \mathrm{C}$ \\
\hline & $\begin{array}{c}\text { Wu et al. (Lancet } \\
\text { Infect Dis 2021) } \\
\text { [39] }\end{array}$ & 04383574 & $1 \& 2$ & 422 & $\begin{array}{c}\text { Intramuscular injections of } \\
\text { inactivated CN02 strain at } \\
\text { day } 0 \text { and } 28 \text { for phase } 1 \text { trial } \\
(3,6 \mu \mathrm{g}) \text {, and at day } 0 \text { for } \\
\text { phase } 2 \text { trial }(1.5,3,6 \mu \mathrm{g})\end{array}$ & $\begin{array}{l}\text { Local and systemic AEs; } \\
\text { SARS-CoV-2 neutralizing } \\
\text { antibody }\end{array}$ & $2-8{ }^{\circ} \mathrm{C}$ \\
\hline & $\begin{array}{c}\text { Che et al. (Clin } \\
\text { Infect Dis 2020) } \\
\text { [40] }\end{array}$ & 04412538 & 2 & 750 & $\begin{array}{l}\text { Injections of inactivated virus } \\
\text { (100 EU or } 150 \text { EU viral } \\
\text { antigen) at day } 0 \text { and boost at } \\
\text { day } 14 \text { or } 28\end{array}$ & $\begin{array}{l}\text { Local, systemic, and unsolicited } \\
\text { AEs; anti-SARS-CoV-2 antibody; } \\
\text { SARS-CoV-2-neutralizing } \\
\text { antibody }\end{array}$ & $\mathrm{N} / \mathrm{A}$ \\
\hline & $\begin{array}{l}\text { Pu et al. (Vaccine } \\
\text { 2021) [41] }\end{array}$ & 04412538 & 1 & 192 & $\begin{array}{c}\text { Intramuscular injections of } \\
\text { inactivated virus with a } \\
\text { D614G mutation in the S } \\
\text { protein (50, 100, or } 150 \mathrm{EU}) \text { at } \\
\text { days } 0 \text { and } 14 \text { or } 28 .\end{array}$ & $\begin{array}{c}\text { Local, systemic, and unsolicited } \\
\text { AEs; Anti-S antibody; } \\
\text { SARS-CoV-2-neutralizing } \\
\text { antibody }\end{array}$ & N/A \\
\hline & $\begin{array}{c}\text { Ella et al. (Lancet } \\
\text { Infect Dis 2021a) } \\
\text { [42] }\end{array}$ & 04471519 & 1 & 375 & $\begin{array}{c}\text { Intramuscular injections of } \\
\text { BBV152 ( } 3 \text { or } 6 \mu \mathrm{g}) \text { at days } 0 \\
\text { and } 14\end{array}$ & $\begin{array}{l}\text { Local and systemic AEs; anti-S } \\
\text { antibody; anti-RBD antibody; } \\
\text { SARS-CoV-2 neutralizing } \\
\text { antibody }\end{array}$ & $2-8^{\circ} \mathrm{C}$ \\
\hline & $\begin{array}{c}\text { Ella et al. (Lancet } \\
\text { Infect Dis 2021b) } \\
\text { [43] }\end{array}$ & 04471519 & 2 & 380 & $\begin{array}{c}\text { Intramuscular injections of } \\
\text { BBV152 ( } 3 \text { or } 6 \mu \mathrm{g}) \text { at days } 0 \\
\text { and } 28\end{array}$ & $\begin{array}{l}\text { Local and systemic AEs; anti-S } \\
\text { antibody; anti-RBD antibody; } \\
\text { SARS-CoV-2-neutralizing } \\
\text { antibody }\end{array}$ & $2-8{ }^{\circ} \mathrm{C}$ \\
\hline $\begin{array}{l}\text { Virus-like } \\
\text { particle }\end{array}$ & $\begin{array}{l}\text { Ward et al. (Nat } \\
\text { Med 2021) [44] }\end{array}$ & 04450004 & 1 & 180 & $\begin{array}{c}\text { Intramuscular injections of } \\
\text { CoVLP }(3.75,7.5, \text { or } 15 \mu \mathrm{g}) \text { at } \\
\text { days } 0 \text { and } 21\end{array}$ & $\begin{array}{c}\text { Local, systemic, and unsolicited } \\
\text { AEs; Anti-S antibody; } \\
\text { SARS-CoV-2-neutralizing } \\
\text { antibody }\end{array}$ & $2-8{ }^{\circ} \mathrm{C}$ \\
\hline
\end{tabular}

Overall safety of the subunit vaccines, defined as the inverse ORs of solicited sys-temic reactions, was derived for solicited systemic reactions of protein-based (Figure 2A, pooled inverse OR $0.53,95 \%$ CI 0.27 to $1.05 ; p=0.07$ ), RNA-based (Figure 2B, pooled inverse OR $0.35,95 \% \mathrm{CI} 0.16$ to $0.75 ; p=0.007$ ), and viral vector-based (Figure $2 \mathrm{C}$, pooled inverse OR $0.32,95 \%$ CI 0.19 to $0.55 ; p<0.0001)$ vaccines, and overall safety of inactivated vaccines were derived for inactivated virus-based vaccines (Figure 2D, pooled inverse OR 1.00, 95\% CI 0.73 to $1.36 ; p=0.98)$. Risks of solicited local reactions were derived for protein vaccines (Figure S2A, pooled inverse OR $0.12,95 \%$ CI 0.06 to $0.24 ; p<0.00001$ ), RNA vaccines (Figure $\mathrm{S} 2 \mathrm{~B}$, pooled inverse OR $0.04,95 \% \mathrm{CI} 0.02$ to $0.07 ; p<0.00001$ ), viral vector vaccines (Figure S2C, pooled inverse OR $0.24,95 \%$ CI 0.09 to $0.64 ; p=0.04$ ), and inactivated virus vaccines (Figure S2D, pooled inverse OR $0.46,95 \%$ CI 0.29 to $0.72 ; p=0.04$ ) in which all four types of vaccine products can induce significant local AEs, compared with placebo/control. Risks of unsolicited AEs were derived for protein vaccines (Figure S3A, pooled inverse OR 0.90, $95 \%$ CI 0.60 to $1.34 ; p=0.6$ ), viral vector vaccines (Figure S3B, pooled inverse OR $0.48,95 \%$ CI 0.30 to $0.77 ; p=0.003$ ), and inactivated virus (Figure S3C, pooled inverse OR $0.73,95 \%$ CI 0.32 to $1.66 ; p=0.46$ ), while there was only one study addressing all unsolicited AEs for RNA vaccines [25].

Vaccination-mediated immune responses against SARS-CoV-2 were defined as seroconversion of at least a fourfold increase in the titers of neutralized antibodies against viral infection [45]. All vaccines can promptly induce seroconversion to block SARS-CoV-2 infection within 28 days post-vaccination. The seroconversion was derived for protein vaccines (Figure $3 \mathrm{~A}$, pooled OR 13.94, 95\% CI 1.87 to $103.65 ; p=0.01$ ), RNA vaccines (Figure 3B, pooled OR 84.86, 95\% CI 13.63 to $528.21 ; p<0.00001$ ), viral vector vaccines (Figure 3C, pooled OR 106.03, 95\% CI 40.73 to $276.03 ; p<0.00001$ ), and inactivated virus vaccines (Figure 3D, pooled OR 451.04, 95\% CI 108.53 to $1874.5 ; p<0.00001$ ). These findings suggest that both protein vaccines and inactivated virus vaccines are more tolerable and safer than RNA vaccines, followed by viral vector vaccines, and that inactivated vaccines have the highest efficacy to rapidly elicit serological responses, followed by viral vector vaccines, than RNA vaccines, and finally, protein vaccines based on their pooled ORs. 
A Study: protein

OR $(95 \% \mathrm{Cl}) \quad$ Weight Chappell 2021 (after boost) Chappell 2021 (after prime) Goepfert 2021 (after boost) Goepfert 2021 (after prime) Richmond 2021 (after boost) Richmond 2021 (after prime) Yang 2021 (Phase 1)

Yang 2021 (Phase 2: three doses)

Yang 2021 (Phase 2: two doses)

Overall effect ( $Z=1.81, p=0.07)$

Note: Weights are from random effect analysis

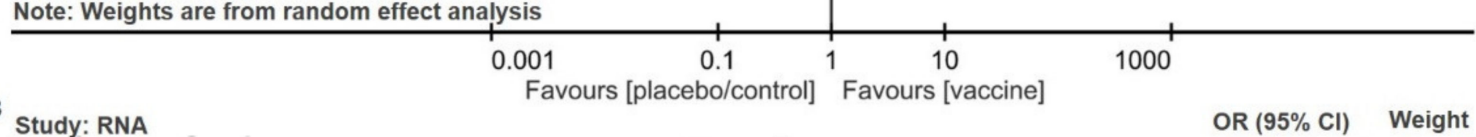

Study: RNA

Favours [placebo/control] Favours [vaccine]

Chu 2021 (after boost)

Chu 2021 (after prime)

Mulligan 2020 (after boost)

Mulligan 2020 (after prime)

Walsh 2020 (after boost)

Walsh 2020 (after prime)

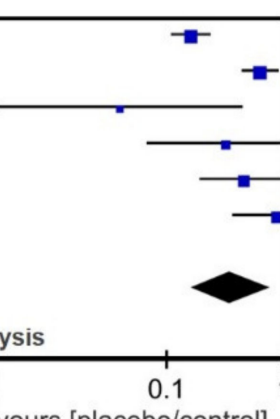

$0.16[0.11,0.24] 22.3 \%$

$0.62[0.44,0.89] 22.4 \%$

$0.04[0.00,0.44] \quad 7.0 \%$

$0.32[0.07,1.48] 12.0 \%$

$0.46[0.19,1.08] 18.1 \%$

$0.87[0.36,2.06] 18.1 \%$

Overall effect $(Z=2.69, p=0.007)$

Note: Weights are from random effect analysis

$\begin{array}{llll}0.001 & 0.1 & 1 & 10 \\ \text { Favours [placebo/control] } & \text { Favours [vaccine] } & 1000\end{array}$

C Study: viral vector

Folegatti 2020

Keech 2020 (after prime)

Ramasamy 2020 (after prime)

Sadoff 2021

Zhu 2020b

Overall effect $(Z=4.11, p<0.0001)$

Favours [placebo/control] Favours [vaccine]

$0.35[0.16,0.75] 100.0 \%$

Study: inactivated virus

OR $(95 \% \mathrm{Cl}) \quad$ Weight

$0.18[0.14,0.24] \quad 23.2 \%$

$0.59[0.24,1.50] \quad 14.3 \%$

$0.71[0.43,1.17] \quad 20.4 \%$

$0.20[0.13,0.29] \quad 21.9 \%$

$0.31[0.19,0.52] \quad 20.2 \%$

$0.32[0.19,0.55] 100.0 \%$

Che 2020 (day 0 \& 14)

Che 2020 (day 0 \& 28)

Ella 2021a (after boost)

Ella 2021a (after prime)

Pu 2021 (day 0 \& 14 vaccination: after boost)

Pu 2021 (day 0 \& 14 vaccination: after prime)

Pu 2021 (day 0 \& 28 vaccination: after boost)

Pu 2021 (day 0 \& 28 vaccination: after prime)

Wu 2021

Zhang 2021 (Phase 1: day 0 \& 14 vaccination)

Zhang 2021 (Phase 1: day 0 \& 28 vaccination)

Zhang 2021 (Phase 2: day 0 \& 14 vaccination)

Zhang 2021 (Phase 2: day 0 \& 28 vaccination)

Overall effect $(Z=0.02, p=0.98)$

Note: Weights are from random effect analysis

$\begin{array}{llcc}0.001 & 0.1 & 1 & 10 \\ \text { Favours [placebo/control] } & \text { Favours [vaccine] } & 1000\end{array}$

OR $(95 \% \mathrm{Cl}) \quad$ Weight

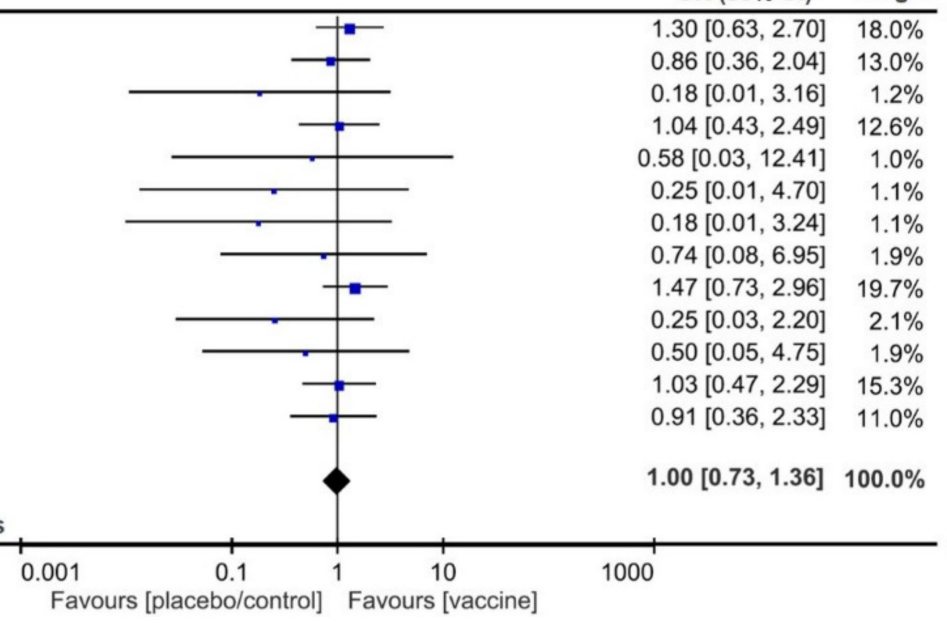

Figure 2. Forest plots for systemic adverse events (AEs) and summary estimates for safety of vaccines, defined as the inverse of sys-temic adverse events (AEs). Numbers of total participants and vaccinated populations with AEs for (A) protein vaccines, (B) RNA vaccines, (C) viral vector vaccines, and (D) inactivated vaccines. Random effect model was used to derive pooled inverse odds ratios (ORs) with 95\% confidence intervals (CIs). 


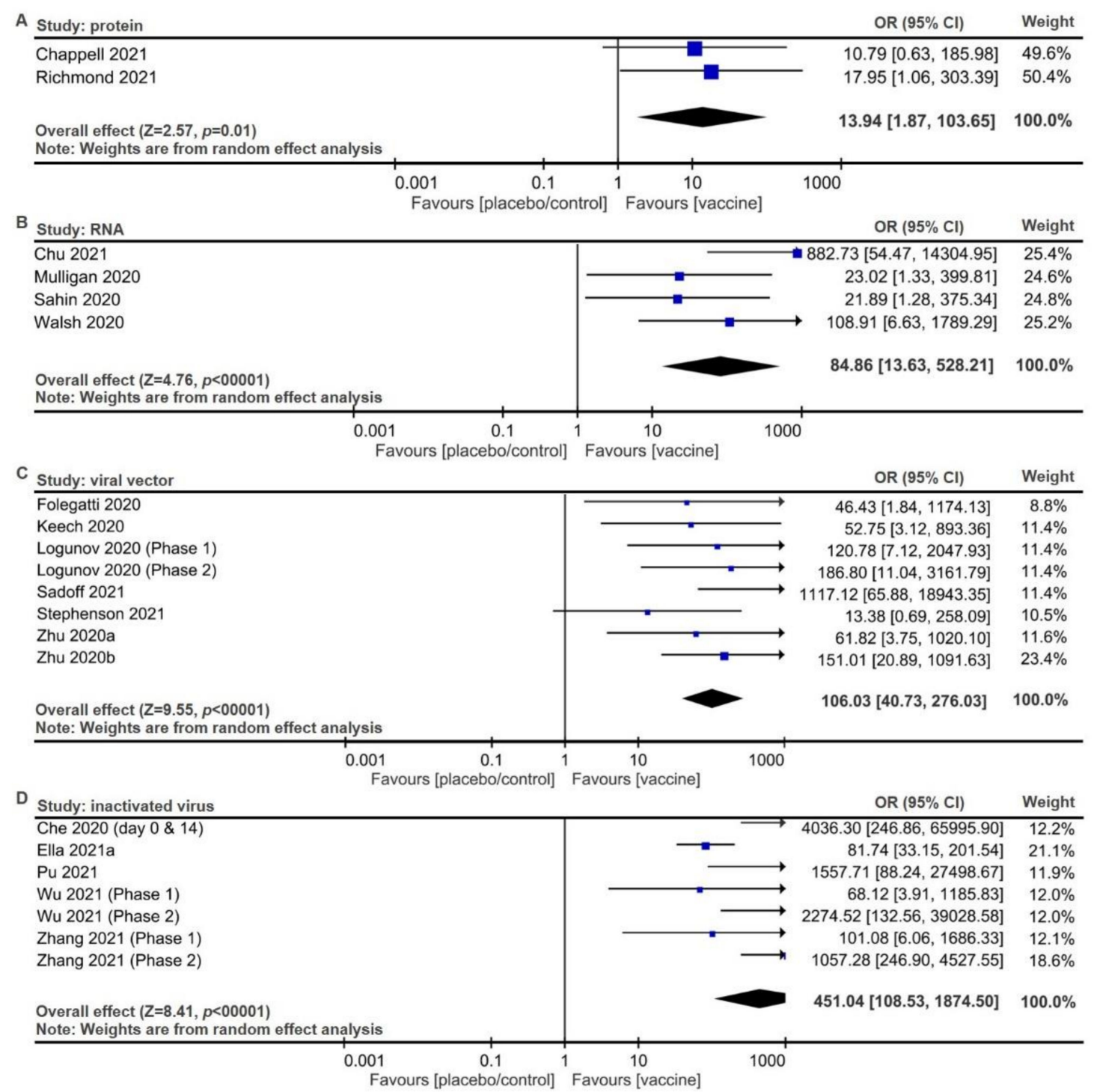

Figure 3. Forest plots for seroconversion to neutralize SARS-CoV-2 among adults inoculated with vaccines. Seroconversion was assessed within 28 days after vaccination of (A) protein vaccines, (B) RNA vaccines, $(\mathbf{C})$ viral vector vaccines, and (D) inactivated vaccines. Random effect model was used to derive pooled ORs with $95 \%$ CIs.

\section{Discussion}

In this systematic review of 389 clinical trials from the NIH Clinical Trial Database and meta-analysis of 27 published reports of the abovementioned trials, as well as one report for trials from the Chinese Clinical Trial Registry, an increasing number of immune-augmentative therapies for COVID-19 was observed. Moreover, the paradigm in this field has been gradually shifting from off-label use of irrelevant vaccines to active immunity induction against SARS-CoV-2, due mainly to their capabilities of providing specific protective immunity against SARS-CoV-2. In our systematic review, immuno-augmentative therapies presented promising immunogenicity and capabilities of reinforcing neutralized antibodies, which realized protective immunity against SARS-CoV-2 but at the same time addressed solicited systemic adverse reactions, solicited local adverse reactions, and unsolicited multiple organ adverse reactions.

With regard to training immunity against the novel pathogen SARS-CoV-2, previous studies have shown their capability to train adaptive immunity, which is immunological memory against specific pathogens [46]. That being said, the paradigm that immunological memory, if and only if it exists, in adaptive immunity has been constantly challenged due to the presence of pattern recognition receptors (PRRs), which are evolutionally conserved 
in most multicellular organisms and can specifically recognize infectious microbes via innate immune cells [47]. As the counterexample to the dogmatic concept, innate immune memory involving PRR-mediated pathways has been reported to cross-protect human bodies from irrelevant pathogens via epigenetic reprogramming in innate immune cells [48]. As a result, heterologous immunity plays a preventive role against novel pathogens that are critically threatening to humans without drugs or vaccines; this role is also known as trained innate immunity [49]. BCG immunization, originally designed for childhood tuberculosis, an infectious disease with high morbidity and mortality rates, has been one of the most prevalent vaccines [9]. Induction of nonspecific protection by BCG vaccination has been demonstrated in both animal and human studies [50,51], including several randomized-controlled trials (RCTs) [52,53]. For instance, BCG vaccination has been shown to cross-protect severe combined immune deficient (SCID) mice from disseminated candidiasis at a survival rescue from $30 \%$ to $100 \%$, with T and B lymphocyte-independent pathways involved [50]. The induced cross-protection in BCG-vaccinated SCID mice was guided by activation of innate receptor nucleotide-binding oligomerization domain-containing protein 2 (NOD2) and epigenetic alterations at histone 3 lysine 4 trimethylation (H3K4me3) site in TLR-4 promoter regions, as well as other inflammatory cytokines in monocytes. Additionally, BCG vaccination has also been suggested to induce genome-wide epigenetic reprogramming of human monocytes and produce IL-1 $\beta$ against viremia caused by yellow fever virus infection in human studies [51]. In such a scenario, epigenetic reprogramming is considered a crucial mechanism of training innate immunity to develop immunological memory by regulating gene activation with histone modification, such asH3K4 methylation or H3K27 acetylation. Similarly, several RCTs have supported BCG vaccination-induced heterologous immunological effect on lowered morbidity and mortality among infants, as well as children suffering from infectious diseases other than TB [52,53]. Therefore, heterologous immunity realized with BCG vaccines has been considered as both a preventive and a therapeutic measure for SARS-CoV-2 infection [54].

A killed or inactivated vaccine refers to the injection of pathogens that have lost their disease-producing capacity but keeps the whole or partial structure consisting of multiple antigens that can be phagocytosed and digested by antigen-presenting cells (APCs), mainly dendritic cells (DCs), to realize adaptive immunity following subcutaneous or intramuscular administration. Then, antigen-loaded APCs via major histocompatibility complex type II (MHC II) molecules would migrate to secondary lymphoid organs to prime naive helper T (Th) cells, which helps antigen-bearing B cells differentiate to either memory B cells or short-lived plasma cells that first secret IgM, then undergo antibody class switching to produce IgG. Since the half-life of IgM is approximately 2 days, isotype switch to IgG would guarantee a prolonged half-life of around 20 days, ensuring the protective effect during infection [55]. In addition to providing multiple antigens, killed or inactivated vaccines are stable and safe but require several doses to elicit an efficient and broadly protective immunity with adjuvant supplements [56]. That being said, the disadvantages of killed or inactivated vaccines include by chance the inactivated pathogen having evolved surface components to escape immune surveillance that would still downregulate immune response during vaccination [57]. Overall, killed or inactivated vaccines have been considered as potential candidates for active immunization against emerging pathogens, for instance, SARS-CoV-2.

Subunit vaccines as a subtype of inactivated vaccines involve immunogenic peptides of pathogens that are designed to trigger APC-mediated T and B cell memory against infectious diseases after subcutaneous or intramuscular administration of multiple doses plus adjuvants. The corresponding process of inducing active immunity is similar to that of killed or activated vaccines. Candidate antigens in subunit vaccines are usually delivered by genetically engineered vectors, such as viral vectors or live bacterial vectors for recombinant DNA vaccines. In the case of coronavirus, $S$ protein as a candidate antigen for both subunit vaccines and neutralizing antibodies would mediate the binding of host cell receptor ACE2 to viral pathogens, with the receptor-binding domains (RBD) of $S$ 
proteins being similar in SARS-CoV-2 and SARS-CoV. Specifically, the S protein comprises two subunits, S1 and S2. The S1 subunit consists of an amino-terminal domain and an RBD. The RBD binds to ACE2 as its host cell target receptor, which starts the infection process. Therefore, subunit vaccines are capable of inducing antigen-specific-neutralizing antibodies that would target $S$ proteins, hence preventing viral spread. These antigens presented in the FDA-approved clinical trials are commonly administered directly or using viral vectors including adenovirus, or bacterial vectors such as probiotics. Additionally, verified nanoparticle-based vaccines for respiratory viruses [58] are also assessed in the registered clinical trials, where the $S$ antigen-encoded mRNAs contained in lipid-composed nanoparticles could directly be translated into functional $\mathrm{S}$ antigens after inoculation.

There are pros and cons of each vaccine design. For instance, DNA vaccines are not as immunogenic as mRNA or protein-based products [59], while mRNA vaccines are not as stable as DNA vaccines. Viral vector vaccines are usually more immunogenic than those using other vectors, yet viral vectors would bring about reduced efficacy due to preexisting immunity to the vector [60]. Subunit vaccines, focusing on S protein, the critical viral protein that binds to ACE2 on the host cells, are considered safer than liveattenuated vaccines and more specific than inactivated vaccines. Based on serological evidence through released studies, most protein vaccines, RNA vaccines, and inactivated vaccines required two doses to provide strong levels of seroconversion with ORs over 100, while viral vector vaccines can require only one dose to reach the comparably strong level of seroconversion (Table 3 and Figure 3). Storage requirements for protein vaccines, DNA vaccines, and inactivated virus vaccines include temperatures around 2 to $8{ }^{\circ} \mathrm{C}\left(36\right.$ to $\left.46^{\circ} \mathrm{F}\right)$, while that for RNA vaccines may vary among products, including (1) 2 to $8{ }^{\circ} \mathrm{C}$ ( 36 to $46^{\circ} \mathrm{F}$ ) for instant use or $-20^{\circ} \mathrm{C}\left(-4{ }^{\circ} \mathrm{F}\right)$ for long-term storage of mRNA-1723, and (2) $-80^{\circ} \mathrm{C}$ $\left(-112^{\circ} \mathrm{F}\right)$ for BNT162b1. Viral vector vaccines are suggested to be stored at 2 to $8{ }^{\circ} \mathrm{C}$ ( 36 to $\left.46^{\circ} \mathrm{F}\right)$ for instant use or $-20^{\circ} \mathrm{C}\left(-4{ }^{\circ} \mathrm{F}\right)$ for long-term storage (Table 3) [61].

Passive immunity refers to the transfer of humoral immunity, in which the involved protective immunoglobulins, IgG, in particular, are derived from immune individuals to neutralize pathogens in non-immune recipients [62]. Vaccines based on artificially acquired passive immunity has been approved for infectious disease prophylaxis and therapeutics, especially when vaccines aiming at long-lasting active immunity are not preferred as those diseases are "races against time" [63]; for example, vaccines that have been shown to reduce mortality among patients with severe viral infections such as influenza A viruses and Ebola viruses would involve the intravenous injection of protective antibodies divided from the convalescent plasma of recovered patients or immunized vaccine recipients $[64,65]$. Likewise, convalescent plasma transfer has been considered as the candidate for immediate treatment for severe COVID-19 patients through measures including direct neutralization and immunomodulation, with the latter involved in (1) the blockage of cytokines or complement, (2) the prevention of DC maturation, or (3) triggering regulatory $\mathrm{T}$ cell development [66-68].

Active immunity is also transferable after immune cells are trained to induce immunity against specific pathogens ex vivo, thus could be considered as immunotherapy. Immunotherapy, which could be traced back to the late 19th century [69], has emerged as a promising treatment of cancer cells as well as infectious diseases [52,70]. For instance, cellular therapies from donor lymphocyte infusion are utilized to treat cancer relapse following allogeneic hematopoietic stem cell transplantation to bring about graft-vs-leukemia reaction [71-73], where antigen-experienced T cells would recognize pathogens such as cytomegalovirus or Epstein-Barr virus. Likewise, antigen-specific T cells acquired by cell expansion or genetically engineered pathogen-specific Tc clones have been applied to infectious diseases [74,75]. In both scenarios, artificial APCs expressing ligands for T cell receptors as well as CD28 co-stimulatory molecules have been developed to prime and expand pathogen-specific effector Tc cells [76]. Moreover, chimeric antigen receptors (CARs) have also been genetically modified in effector cells such as T cells and NK cells, with an extracellular receptor recognizing specific antigens linked plus an intracellular signaling 
molecule that would activate signal cascades [52]. Conforming to the above principles, clinical trials on COVID-19 patients using APCs and effector lymphocytes including Tc and NK cells have been evaluated for safety and efficacy.

\section{Challenges and Perspectives}

Although elicited active immunity following vaccination provides long-lasting prophylactic immunity against pathogens, how long it takes might exceed the time window for treatment. On the contrary, passive immunity allows for immediate protective immunity by the adoptive transfer of hyperimmunoglobulin derived from convalescent donors. That being said, these non-neutralizing or sub-neutralizing antibodies might bring about either viral infection in target cells expressing Fc receptors, also known as antibody-dependent enhancement (ADE), or immunopathology involving immune cell-mediated cytotoxicity in infected cells that could further induce exaggerated immune reactions, also known as antibody-dependent cellular cytotoxicity (ADCC), both being suggested in previous studies on SARS-CoV-2 [77]. Hence, it requires purification and production of neutralizing antibodies to improve the prognosis of patients with severe COVID-19.

Apart from convalescent donation, direct transfer of cellular immunity could also be achieved through the transfer of ex vivo trained active immunity, also known as immunotherapy. For instance, one trial used engineered ACE2-CAR-NKs to target SARS$\mathrm{CoV}$-2-infected cells presenting $\mathrm{S}$ proteins, and to activate downstream signal transduction, imitating the use of CAR-NKs in cancer immunotherapy [78]. Unlike CAR-T therapy, in which unregulated substantial toxic effects have been clinically observed, activated ACE2CAR-NKs could be suppressed when attaching to uninfected/healthy cells. Specifically, MHC I molecules expressed by uninfected cells can be recognized by inhibitory receptors of NK cells, followed by inhibitory signal transmission and cytotoxicity alleviation in healthy cells that are facilitated by killer immunoglobulin-like receptors such as KIR2DL and KIR3DL, or C-type lectin receptors including CD94/NKG2A and CD94/NKG2B [79]. Allogenic ACE2-CAR-NK transplantation could thus be an off-the-shelf product for patients with severe COVID-19, although again it takes extensive time and cost.

There are several limitations of this meta-analysis. First, as antibody response or seroconversion rate for each participant were available in phase 2 but not in phase 3 clinical trials, long-term efficacy on the risk of COVID-19 and 28-day efficacy of serum level can not be acquired at the same time through reports on clinical trials of the same phase. Thus, in our study, only seroconversion level but not population efficacy was discussed. Further, although through the 27 reports of clinical trials, we observed the seroconversion and risk of AEs among protein, DNA, RNA, and viral vector vaccines, while delivery systems such as liposome-encapsulated RNA vaccines may improve both antibody response and safety of individual vaccines [80]. As such, future vaccines with optimized delivery may present better safety than that estimated in our meta-analysis. Lastly, due to the limited number of clinical trials reporting on participants with pre-existing chronic diseases, including diabetes mellitus, chronic kidney disease, rheumatic diseases, or participants that were children, we could not determine the safety and seroconversion efficacy of each vaccine on these subgroups.

\section{Conclusions}

In summary, without effective new drugs, immunity manipulation has been considered a promising option to defend against infection. As prophylactic and therapeutic immunity is crucial to fight against SARS-CoV-2 at different stages of disease progression, clinical trials have been launched to evaluate the safety and seroconversion of strategies to manipulate immunity. These trials involve off-the-shelf BCG vaccines for heterologous immunity against SARS-CoV-2 in healthcare providers and direct transfer of immunoglobulin from convalescent donors or ex vivo trained immune cells for preventing viral dissemination or eliminating infected cells in COVID-19 patients, as well as conventional vaccines containing inactivated virus or subunit of pathogens eliciting Th-dependent B memory 
pathway for specific prophylaxis in healthy adults (Figure 4). Trends toward vaccineinduced active immunity were eminent in clinical trials included for the present systemic review and meta-analysis. The efficacy of humoral immune responses against SARS-CoV-2 for these vaccines was promising, although systemic adverse events were still evident for RNA-based vaccines and viral vector-based vaccines. Further studies are warranted to investigate the underlying mechanisms of effective manipulation of immune responses against COVID-19 with minimized adverse effects.

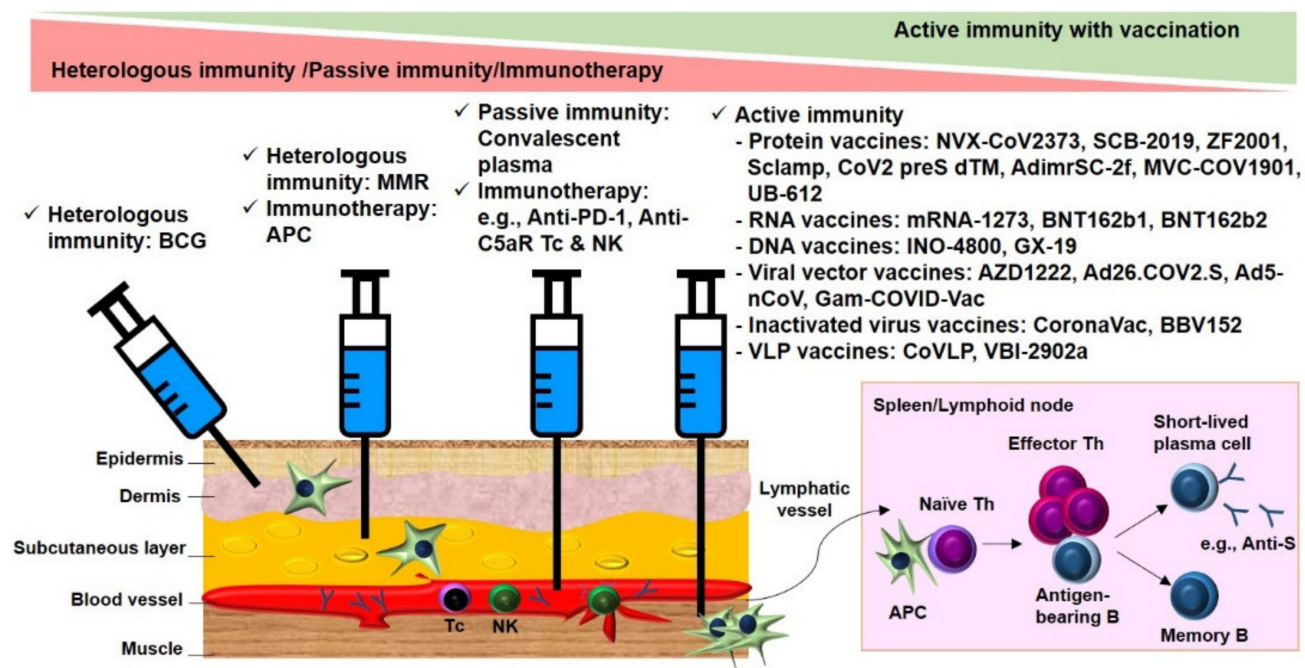

Figure 4. Summary of clinical trials on immune augmentation against SARS-CoV-2 infection. Clinical trials ranged from off-the-shelf BCG or MMR vaccines that aimed at inducing protective heterologous immunity against COVID-19 for healthcare professionals, to direct transfer of hyperimmunoglobulin or ex vivo trained immune cells that aimed at preventing viral dissemination or direct killing of infected cells in COVID-19 patients, then to conventional vaccines with protein vaccines, RNA vaccines, DNA vaccines, viral vector vaccines, inactivated virus vaccines, and VLP vaccines that aimed at COVID-19 prophylaxis via eliciting Th-dependent B memory pathways in healthy adults. BCG, Bacillus Calmette-Guérin; APC, antigen-presenting cell; PD-1: programmed cell death protein1; Tc, cytotoxic T; NK, natural killer; $\mathrm{C} 5 \mathrm{aR}$, component 5a receptor; VLP, virus-like particle.

\section{Materials and Methods}

This study was conducted in accordance with the Preferred Reporting Items for Systematic Review and Meta-analysis of Diagnostic Test Accuracy Studies [81] and Metaanalyses Of Observational Studies in Epidemiology guidelines [82]. Patients or the public were not involved in the design, or conduct, or reporting, or dissemination plans of this research. Inclusion and exclusion criteria are demonstrated in Figure 5.

For the systematic review, we included clinical trials registered on the National Institutes of Health (NIH) Clinical Trial Database (https: / / clinicaltrials.gov / accessed on 25 May 2021) that incorporated keywords vaccination and immunity up to 25 May 2021. The search strategy was either "COVID-19" AND "Immune", or "COVID-19" AND "Vaccine" (Figure 5). To ensure that these trials involve immuno-augmentative mechanisms for developing COVID-19 therapies (Figure 5), four authors (K.S.M., C.C.L., K.J.L, and L.T.W.) screened the trials and identified 389 eligible trials that directly manipulated immunity, including 32 trials that induced training immunity via vaccination, 249 trials that induced active immunity via vaccination, 59 trials that transferred passive immunity, and 59 trials on immunomodulation or enhancement of antiviral immunity based on immunotherapies (Supplementary Table S2). 


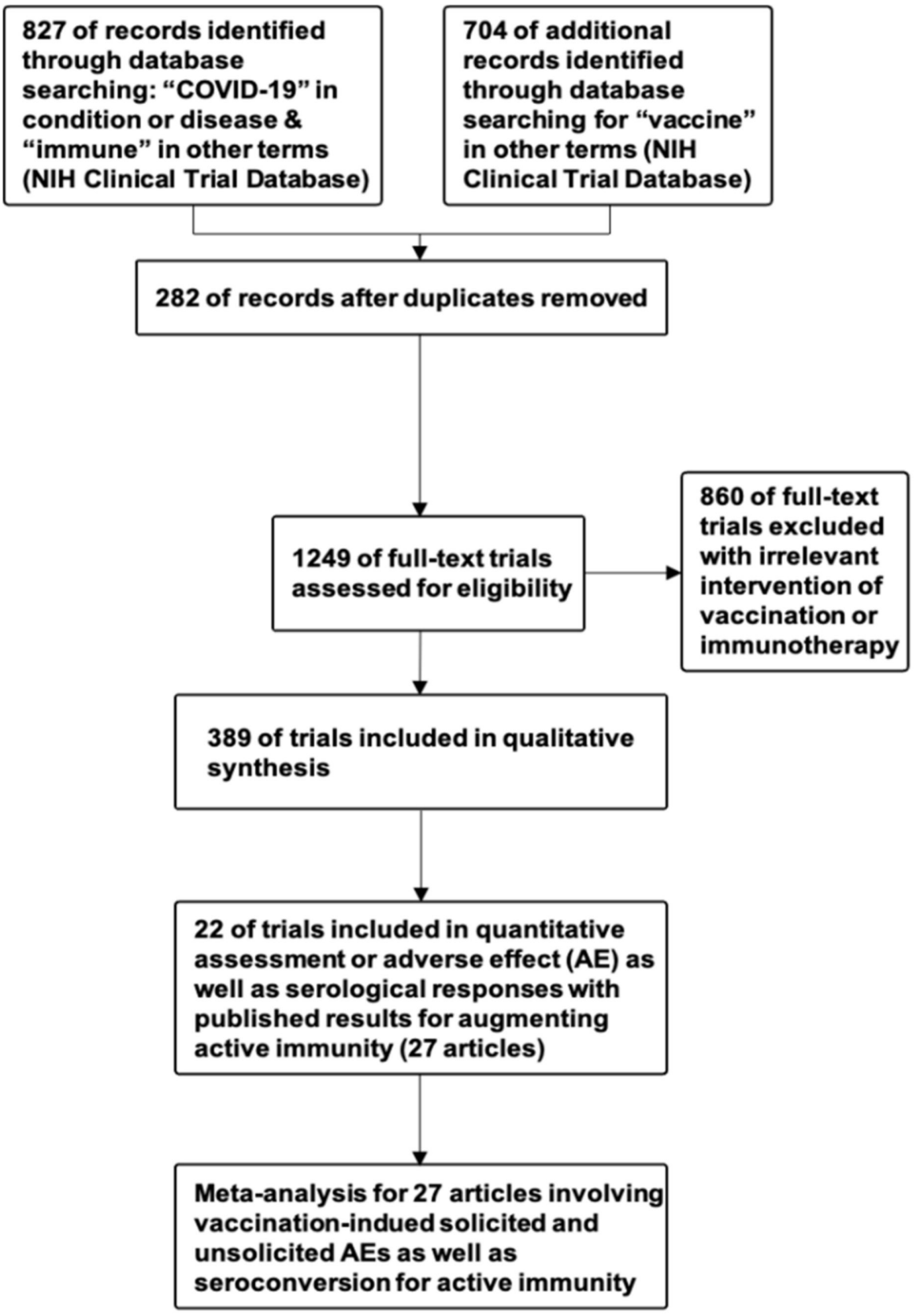

Figure 5. PRISMA flow diagram for selection of clinical trials and published results for meta-analysis.

As for epidemiological data on registered COVID-19 cases in countries with or without Bacillus Calmette-Guérin (BCG) vaccination policy, we estimated the respective COVID-19 mortality rate registered on 12 September at Johns Hopkins Centers for Civic Impact [4] and accordingly evaluated BCG programs among high-income countries listed in the BCG World Atlas [9].

To determine whether, in populations at risk for COVID-19 or patients with COVID-19, there is any difference in antibody response and safety with the four different types of vaccines, including protein vaccines, RNA vaccines, viral vector vaccines, and inactivated vaccines, we performed this systematic review and meta-analysis. In particular, the antibody response was defined as post-vaccination seroconversion levels, and safety was defined as post-vaccination adverse events (AEs), including solicited systemic reactions, solicited local reactions, unsolicited AEs. For the meta-analysis of released results of clinical trials in augmenting active immunity (Figure 5), we searched PubMed, Embase, Scopus, and the Cochrane Central Register of Controlled Trials for articles published through 
25 May 2021 that incorporated the trial numbers of included clinical trials registered on the NIH Clinical Trial Database, and identified 27 original articles demonstrating safety and seroconversion of tested trials. The 27 published articles included five for protein-based vaccines [18-22], six for RNA-based vaccines [23-28], one for DNA-based vaccine [29], eight for viral vectors [30-37], six for inactivated viruses [38-43], and one for virus-like particles (VLPs) [44]. Four authors (K.S.M., C.C.L., K.J.L, and L.T.W.) extracted data on study demographics and both primary and secondary outcomes. The primary outcome was overall safety evinced by post-vaccination AEs in terms of (1) systemic AEs such as fever and fatigue, (2) local reactogenicity or local AEs such as pain and tenderness, and (3) unexpected or unsolicited AEs categorized following the World Health Organization guidance $[11,83,84]$. The secondary outcome was immunogenicity, as evinced by data on seroconversion.

\section{Statistical Analysis}

Student's $t$-test was used to compare the differences (mean $\pm \mathrm{SD}$ ) between the intervention and the control group using GraphPad Prism software (CA, USA). A value of $p<0.05$ was considered statistically significant. Meta-analysis of protein-, RNA-, viral vector-, and inactivated virus-based vaccines were conducted for pooled odds ratios (ORs) with 95\% confidence intervals (CIs) with random effect model using RevMan5 software (Cochrane Collaboration) [85].

Supplementary Materials: The following are available online at https:/ / www.mdpi.com/article/10 .3390 / pathogens10121537/s1, Table S1: Epidemiological data on COVID-19 cases and CG programs among high income countries, Table S2: Clinical trials for immune augmentation against SARS$\mathrm{CoV}-2$ virus infection; Figure S1: Epide-miological analyses revealed comparatively low mortality for COVID-19 in high-income countries with BCG vaccination policies; Figure S2: Forest plots and summary estimates for safety of vaccines, defined as the inverse of local adverse events (AEs); Figure S3: Forest plots and summary estimates for safety of vaccines, defined as the inverse of unsolicited AEs.

Author Contributions: Conceptualization, K.S.-K.M. and L.-T.W.; methodology, K.S.-K.M., C.-C.L., K.-J.L., J.C.-C.W. and L.-T.W.; writing-original draft preparation, K.S.-K.M. and L.-T.W.; writingreview and editing, K.S.-K.M., Y.-T.L. and L.-T.W.; funding acquisition, K.S.-K.M., Y.-T.L. and L.-T.W. All authors have read and agreed to the published version of the manuscript.

Funding: This work was supported in part by funding from the Taiwan Ministry of Science and Technology (MOST: 108-2813-C-040-040-B to K.S.M. and 109-2326-B-002-016-MY3 to L.T.W.), Chung Shan Medical University Hospital, Taiwan (CSH-2020-C-011 to Y.T.L.), and a research grant from International Team for Implantology (fund no. 1577_2021 to K.S.M.).

Institutional Review Board Statement: Not applicable.

Informed Consent Statement: Not applicable.

Data Availability Statement: Not applicable.

Acknowledgments: The authors would like to thank Rafi Ahmed (Emory University) and Michael Karin (University of California, San Diego, CA, USA) for constructive discussion and comments on the presenting data.

Conflicts of Interest: The authors declare no competing interests.

\section{References}

1. Ma, K.S.; Tsai, S.Y. Big Data-driven personal protective equipment stockpiling framework under Universal Healthcare for Disease Control and Prevention in the COVID-19 Era. Int. J. Surg. 2020, 79, 290-291. [CrossRef]

2. Ma, K.S. Integrating travel history via big data analytics under universal healthcare framework for disease control and prevention in the COVID-19 pandemic. J. Clin. Epidemiol. 2021, 130, 147-148. [CrossRef] [PubMed]

3. Khailany, R.A.; Safdar, M.; Ozaslan, M. Genomic characterization of a novel SARS-CoV-2. Gene Rep. 2020, 19, 100682. [CrossRef]

4. Dong, E.; Du, H.; Gardner, L. An interactive web-based dashboard to track COVID-19 in real time. Lancet Infect. Dis. 2020, 20, 533-534. [CrossRef] 
5. Bonam, S.R.; Kaveri, S.V.; Sakuntabhai, A.; Gilardin, L.; Bayry, J. Adjunct Immunotherapies for the Management of Severely Ill COVID-19 Patients. Cell Rep. Med. 2020, 1, 100016. [CrossRef]

6. Netea, M.G.; Joosten, L.A.; Latz, E.; Mills, K.H.; Natoli, G.; Stunnenberg, H.G.; O'Neill, L.A.; Xavier, R.J. Trained immunity: A program of innate immune memory in health and disease. Science 2016, 352, aaf1098. [CrossRef]

7. Gerth, H.J. [Basic principles of active and passive immunizations]. Internist 1979, 20, 264-272.

8. Yang, Y. Cancer immunotherapy: Harnessing the immune system to battle cancer. J. Clin. Invest. 2015, 125, 3335-3337. [CrossRef] [PubMed]

9. Zwerling, A.; Behr, M.A.; Verma, A.; Brewer, T.F.; Menzies, D.; Pai, M. The BCG World Atlas: A database of global BCG vaccination policies and practices. PLoS Med. 2011, 8, e1001012. [CrossRef] [PubMed]

10. Zimmermann, P.; Perrett, K.P.; van der Klis, F.R.; Curtis, N. The immunomodulatory effects of measles-mumps-rubella vaccination on persistence of heterologous vaccine responses. Immunol. Cell Biol. 2019, 97, 577-585. [CrossRef]

11. Ma, K.S.; Saeed, H.N.; Chodosh, J.; Wang, C.W.; Chung, Y.C.; Wei, L.C.; Kuo, M.T.; Liang, C.M.; Chang, J.W.; Chung, W.H.; et al. Ocular manifestations of anti-neoplastic immune checkpoint inhibitor-associated Stevens-Johnson syndrome/toxic epidermal necrolysis in cancer patients. Ocul. Surf. 2021, 22, 47-50. [CrossRef] [PubMed]

12. Vabret, N.; Britton, G.J.; Gruber, C.; Hegde, S.; Kim, J.; Kuksin, M.; Levantovsky, R.; Malle, L.; Moreira, A.; Park, M.D.; et al. Immunology of COVID-19: Current State of the Science. Immunity 2020, 52, 910-941. [CrossRef] [PubMed]

13. Zheng, M.; Gao, Y.; Wang, G.; Song, G.; Liu, S.; Sun, D.; Xu, Y.; Tian, Z. Functional exhaustion of antiviral lymphocytes in COVID-19 patients. Cell Mol. Immunol. 2020, 17, 533-535. [CrossRef]

14. Risitano, A.M.; Mastellos, D.C.; Huber-Lang, M.; Yancopoulou, D.; Garlanda, C.; Ciceri, F.; Lambris, J.D. Complement as a target in COVID-19? Nat. Rev. Immunol. 2020. [CrossRef]

15. Xu, X.; Han, M.; Li, T.; Sun, W.; Wang, D.; Fu, B.; Zhou, Y.; Zheng, X.; Yang, Y.; Li, X.; et al. Effective treatment of severe COVID-19 patients with tocilizumab. Proc. Natl. Acad. Sci. USA 2020, 117, 10970-10975. [CrossRef] [PubMed]

16. Laterre, P.F.; Francois, B.; Collienne, C.; Hantson, P.; Jeannet, R.; Remy, K.E.; Hotchkiss, R.S. Association of Interleukin 7 Immunotherapy With Lymphocyte Counts Among Patients With Severe Coronavirus Disease 2019 (COVID-19). JAMA Netw. Open 2020, 3, e2016485. [CrossRef]

17. Sa Ribero, M.; Jouvenet, N.; Dreux, M.; Nisole, S. Interplay between SARS-CoV-2 and the type I interferon response. PLoS Pathog. 2020, 16, e1008737. [CrossRef] [PubMed]

18. Keech, C.; Albert, G.; Cho, I.; Robertson, A.; Reed, P.; Neal, S.; Plested, J.S.; Zhu, M.; Cloney-Clark, S.; Zhou, H.; et al. Phase 1-2 Trial of a SARS-CoV-2 Recombinant Spike Protein Nanoparticle Vaccine. N. Engl. J. Med. 2020. [CrossRef] [PubMed]

19. Richmond, P.; Hatchuel, L.; Dong, M.; Ma, B.; Hu, B.; Smolenov, I.; Li, P.; Liang, P.; Han, H.H.; Liang, J.; et al. Safety and immunogenicity of S-Trimer (SCB-2019), a protein subunit vaccine candidate for COVID-19 in healthy adults: A phase 1, randomised, double-blind, placebo-controlled trial. Lancet 2021, 397, 682-694. [CrossRef]

20. Yang, S.; Li, Y.; Dai, L.; Wang, J.; He, P.; Li, C.; Fang, X.; Wang, C.; Zhao, X.; Huang, E.; et al. Safety and immunogenicity of a recombinant tandem-repeat dimeric RBD-based protein subunit vaccine (ZF2001) against COVID-19 in adults: Two randomised, double-blind, placebo-controlled, phase 1 and 2 trials. Lancet Infect. Dis. 2021, 21, 1107-1119. [CrossRef]

21. Chappell, K.J.; Mordant, F.L.; Li, Z.; Wijesundara, D.K.; Ellenberg, P.; Lackenby, J.A.; Cheung, S.T.M.; Modhiran, N.; Avumegah, M.S.; Henderson, C.L.; et al. Safety and immunogenicity of an MF59-adjuvanted spike glycoprotein-clamp vaccine for SARS-CoV2: A randomised, double-blind, placebo-controlled, phase 1 trial. Lancet Infect. Dis. 2021, 21, 1383-1394. [CrossRef]

22. Goepfert, P.A.; Fu, B.; Chabanon, A.L.; Bonaparte, M.I.; Davis, M.G.; Essink, B.J.; Frank, I.; Haney, O.; Janosczyk, H.; Keefer, M.C.; et al. Safety and immunogenicity of SARS-CoV-2 recombinant protein vaccine formulations in healthy adults: Interim results of a randomised, placebo-controlled, phase 1-2, dose-ranging study. Lancet Infect. Dis. 2021. [CrossRef]

23. Anderson, E.J.; Rouphael, N.G.; Widge, A.T.; Jackson, L.A.; Roberts, P.C.; Makhene, M.; Chappell, J.D.; Denison, M.R.; Stevens, L.J.; Pruijssers, A.J.; et al. Safety and Immunogenicity of SARS-CoV-2 mRNA-1273 Vaccine in Older Adults. N. Engl. J. Med. 2020, 383, 2427-2438. [CrossRef]

24. Chu, L.; McPhee, R.; Huang, W.; Bennett, H.; Pajon, R.; Nestorova, B.; Leav, B.; on behalf of mRNA-1273 Study Group. A preliminary report of a randomized controlled phase 2 trial of the safety and immunogenicity of mRNA-1273 SARS-CoV-2 vaccine. Vaccine 2021, 39, 2791-2799. [CrossRef]

25. Jackson, L.A.; Anderson, E.J.; Rouphael, N.G.; Roberts, P.C.; Makhene, M.; Coler, R.N.; McCullough, M.P.; Chappell, J.D.; Denison, M.R.; Stevens, L.J.; et al. An mRNA Vaccine against SARS-CoV-2-Preliminary Report. N. Engl. J. Med. 2020, 383, $1920-1931$. [CrossRef] [PubMed]

26. Mulligan, M.J.; Lyke, K.E.; Kitchin, N.; Absalon, J.; Gurtman, A.; Lockhart, S.; Neuzil, K.; Raabe, V.; Bailey, R.; Swanson, K.A.; et al. Phase I/II study of COVID-19 RNA vaccine BNT162b1 in adults. Nature 2020, 586, 589-593. [CrossRef] [PubMed]

27. Sahin, U.; Muik, A.; Derhovanessian, E.; Vogler, I.; Kranz, L.M.; Vormehr, M.; Baum, A.; Pascal, K.; Quandt, J.; Maurus, D.; et al. COVID-19 vaccine BNT162b1 elicits human antibody and TH1 T cell responses. Nature 2020, 586, 594-599. [CrossRef] [PubMed]

28. Walsh, E.E.; Frenck, R.W., Jr.; Falsey, A.R.; Kitchin, N.; Absalon, J.; Gurtman, A.; Lockhart, S.; Neuzil, K.; Mulligan, M.J.; Bailey, R.; et al. Safety and Immunogenicity of Two RNA-Based Covid-19 Vaccine Candidates. N. Engl. J. Med. 2020, 383, 2439-2450. [CrossRef] [PubMed] 
29. Tebas, P.; Yang, S.; Boyer, J.D.; Reuschel, E.L.; Patel, A.; Christensen-Quick, A.; Andrade, V.M.; Morrow, M.P.; Kraynyak, K.; Agnes, J.; et al. Safety and immunogenicity of INO-4800 DNA vaccine against SARS-CoV-2: A preliminary report of an open-label, Phase 1 clinical trial. EClinicalMedicine 2021, 31, 100689. [CrossRef] [PubMed]

30. Zhu, F.C.; Li, Y.H.; Guan, X.H.; Hou, L.H.; Wang, W.J.; Li, J.X.; Wu, S.P.; Wang, B.S.; Wang, Z.; Wang, L.; et al. Safety, tolerability, and immunogenicity of a recombinant adenovirus type-5 vectored COVID-19 vaccine: A dose-escalation, open-label, non-randomised, first-in-human trial. Lancet 2020, 395, 1845-1854. [CrossRef]

31. Folegatti, P.M.; Ewer, K.J.; Aley, P.K.; Angus, B.; Becker, S.; Belij-Rammerstorfer, S.; Bellamy, D.; Bibi, S.; Bittaye, M.; Clutterbuck, E.A.; et al. Safety and immunogenicity of the ChAdOx1 nCoV-19 vaccine against SARS-CoV-2: A preliminary report of a phase 1/2, single-blind, randomised controlled trial. Lancet 2020, 396, 467-478. [CrossRef]

32. Barrett, J.R.; Belij-Rammerstorfer, S.; Dold, C.; Ewer, K.J.; Folegatti, P.M.; Gilbride, C.; Halkerston, R.; Hill, J.; Jenkin, D.; Stockdale, L.; et al. Phase $1 / 2$ trial of SARS-CoV-2 vaccine ChAdOx1 nCoV-19 with a booster dose induces multifunctional antibody responses. Nat. Med. 2021, 27, 279-288. [CrossRef] [PubMed]

33. Zhu, F.C.; Guan, X.H.; Li, Y.H.; Huang, J.Y.; Jiang, T.; Hou, L.H.; Li, J.X.; Yang, B.F.; Wang, L.; Wang, W.J.; et al. Immunogenicity and safety of a recombinant adenovirus type-5-vectored COVID-19 vaccine in healthy adults aged 18 years or older: A randomised, double-blind, placebo-controlled, phase 2 trial. Lancet 2020, 396, 479-488. [CrossRef]

34. Ramasamy, M.N.; Minassian, A.M.; Ewer, K.J.; Flaxman, A.L.; Folegatti, P.M.; Owens, D.R.; Voysey, M.; Aley, P.K.; Angus, B.; Babbage, G.; et al. Safety and immunogenicity of ChAdOx1 nCoV-19 vaccine administered in a prime-boost regimen in young and old adults (COV002): A single-blind, randomised, controlled, phase 2/3 trial. Lancet 2021, 396, 1979-1993. [CrossRef]

35. Sadoff, J.; Gray, G.; Vandebosch, A.; Cardenas, V.; Shukarev, G.; Grinsztejn, B.; Goepfert, P.A.; Truyers, C.; Fennema, H.; Spiessens, B.; et al. Safety and Efficacy of Single-Dose Ad26.COV2.S Vaccine against Covid-19. N. Engl. J. Med. 2021, 384, $2187-2201$. [CrossRef] [PubMed]

36. Stephenson, K.E.; Le Gars, M.; Sadoff, J.; de Groot, A.M.; Heerwegh, D.; Truyers, C.; Atyeo, C.; Loos, C.; Chandrashekar, A.; McMahan, K.; et al. Immunogenicity of the Ad26.COV2.S Vaccine for COVID-19. JAMA 2021, 325, 1535-1544. [CrossRef]

37. Logunov, D.Y.; Dolzhikova, I.V.; Zubkova, O.V.; Tukhvatulin, A.I.; Shcheblyakov, D.V.; Dzharullaeva, A.S.; Grousova, D.M.; Erokhova, A.S.; Kovyrshina, A.V.; Botikov, A.G.; et al. Safety and immunogenicity of an rAd26 and rAd5 vector-based heterologous prime-boost COVID-19 vaccine in two formulations: Two open, non-randomised phase $1 / 2$ studies from Russia. Lancet 2020, 396, 887-897. [CrossRef]

38. Zhang, Y.; Zeng, G.; Pan, H.; Li, C.; Hu, Y.; Chu, K.; Han, W.; Chen, Z.; Tang, R.; Yin, W.; et al. Safety, tolerability, and immunogenicity of an inactivated SARS-CoV-2 vaccine in healthy adults aged 18-59 years: A randomised, double-blind, placebocontrolled, phase $1 / 2$ clinical trial. Lancet Infect. Dis. 2021, 21, 181-192. [CrossRef]

39. Wu, Z.; Hu, Y.; Xu, M.; Chen, Z.; Yang, W.; Jiang, Z.; Li, M.; Jin, H.; Cui, G.; Chen, P.; et al. Safety, tolerability, and immunogenicity of an inactivated SARS-CoV-2 vaccine (CoronaVac) in healthy adults aged 60 years and older: A randomised, double-blind, placebo-controlled, phase $1 / 2$ clinical trial. Lancet Infect. Dis. 2021, 21, 803-812. [CrossRef]

40. Che, Y.; Liu, X.; Pu, Y.; Zhou, M.; Zhao, Z.; Jiang, R.; Yin, Z.; Xu, M.; Yin, Q.; Wang, J.; et al. Randomized, double-blinded and placebo-controlled phase II trial of an inactivated SARS-CoV-2 vaccine in healthy adults. Clin. Infect. Dis. 2020, ciaa1703. [CrossRef]

41. Pu, J.; Yu, Q.; Yin, Z.; Zhang, Y.; Li, X.; Yin, Q.; Chen, H.; Long, R.; Zhao, Z.; Mou, T.; et al. The safety and immunogenicity of an inactivated SARS-CoV-2 vaccine in Chinese adults aged 18-59 years: A phase I randomized, double-blinded, controlled trial. Vaccine 2021, 39, 2746-2754. [CrossRef] [PubMed]

42. Ella, R.; Vadrevu, K.M.; Jogdand, H.; Prasad, S.; Reddy, S.; Sarangi, V.; Ganneru, B.; Sapkal, G.; Yadav, P.; Abraham, P.; et al. Safety and immunogenicity of an inactivated SARS-CoV-2 vaccine, BBV152: A double-blind, randomised, phase 1 trial. Lancet Infect. Dis. 2021, 21, 637-646. [CrossRef]

43. Ella, R.; Reddy, S.; Jogdand, H.; Sarangi, V.; Ganneru, B.; Prasad, S.; Das, D.; Raju, D.; Praturi, U.; Sapkal, G.; et al. Safety and immunogenicity of an inactivated SARS-CoV-2 vaccine, BBV152: Interim results from a double-blind, randomised, multicentre, phase 2 trial, and 3-month follow-up of a double-blind, randomised phase 1 trial. Lancet Infect. Dis. 2021, 21, 950-961. [CrossRef]

44. Ward, B.J.; Gobeil, P.; Seguin, A.; Atkins, J.; Boulay, I.; Charbonneau, P.Y.; Couture, M.; D'Aoust, M.A.; Dhaliwall, J.; Finkle, C.; et al. Phase 1 randomized trial of a plant-derived virus-like particle vaccine for COVID-19. Nat. Med. 2021, 27, 1071-1078. [CrossRef]

45. Piantadosi, A.; Kanjilal, S. Diagnostic Approach for Arboviral Infections in the United States. J. Clin. Microbiol. 2020, 58, e01926-19. [CrossRef]

46. Aaby, P.; Benn, C.S. Saving lives by training innate immunity with bacille Calmette-Guerin vaccine. Proc. Natl. Acad. Sci. USA 2012, 109, 17317-17318. [CrossRef] [PubMed]

47. Medzhitov, R.; Janeway, C., Jr. Innate immune recognition: Mechanisms and pathways. Immunol. Rev. 2000, 173, 89-97. [CrossRef] [PubMed]

48. Rusek, P.; Wala, M.; Druszczynska, M.; Fol, M. Infectious Agents as Stimuli of Trained Innate Immunity. Int. J. Mol. Sci. 2018, 19, 456. [CrossRef] [PubMed]

49. Netea, M.G.; Dominguez-Andres, J.; Barreiro, L.B.; Chavakis, T.; Divangahi, M.; Fuchs, E.; Joosten, L.A.B.; van der Meer, J.W.M.; Mhlanga, M.M.; Mulder, W.J.M.; et al. Defining trained immunity and its role in health and disease. Nat. Rev. Immunol. 2020, 20, 375-388. [CrossRef] 
50. Kleinnijenhuis, J.; Quintin, J.; Preijers, F.; Joosten, L.A.; Ifrim, D.C.; Saeed, S.; Jacobs, C.; van Loenhout, J.; de Jong, D.; Stunnenberg, H.G.; et al. Bacille Calmette-Guerin induces NOD2-dependent nonspecific protection from reinfection via epigenetic reprogramming of monocytes. Proc. Natl. Acad. Sci. USA 2012, 109, 17537-17542. [CrossRef] [PubMed]

51. Arts, R.J.W.; Moorlag, S.; Novakovic, B.; Li, Y.; Wang, S.Y.; Oosting, M.; Kumar, V.; Xavier, R.J.; Wijmenga, C.; Joosten, L.A.B.; et al. BCG Vaccination Protects against Experimental Viral Infection in Humans through the Induction of Cytokines Associated with Trained Immunity. Cell Host Microbe 2018, 23, 89-100.e105. [CrossRef]

52. Parida, S.K.; Poiret, T.; Zhenjiang, L.; Meng, Q.; Heyckendorf, J.; Lange, C.; Ambati, A.S.; Rao, M.V.; Valentini, D.; Ferrara, G.; et al. T-Cell Therapy: Options for Infectious Diseases. Clin. Infect. Dis. 2015, 61 (Suppl. S3), S217-S224. [CrossRef] [PubMed]

53. Haahr, S.; Michelsen, S.W.; Andersson, M.; Bjorn-Mortensen, K.; Soborg, B.; Wohlfahrt, J.; Melbye, M.; Koch, A. Non-specific effects of BCG vaccination on morbidity among children in Greenland: A population-based cohort study. Int. J. Epidemiol. 2016, 45, 2122-2130. [CrossRef] [PubMed]

54. Netea, M.G.; Giamarellos-Bourboulis, E.J.; Dominguez-Andres, J.; Curtis, N.; van Crevel, R.; van de Veerdonk, F.L.; Bonten, M. Trained Immunity: A Tool for Reducing Susceptibility to and the Severity of SARS-CoV-2 Infection. Cell 2020, 181, 969-977. [CrossRef] [PubMed]

55. Watson, D.C.; Robbins, J.B.; Szu, S.C. Protection of mice against Salmonella typhimurium with an O-specific polysaccharideprotein conjugate vaccine. Infect. Immun. 1992, 60, 4679-4686. [CrossRef] [PubMed]

56. Ghimire, T.R. The mechanisms of action of vaccines containing aluminum adjuvants: An in vitro vs in vivo paradigm. Springerplus 2015, 4, 181. [CrossRef] [PubMed]

57. Baxter, D. Active and passive immunity, vaccine types, excipients and licensing. Occup. Med. 2007, 57, 552-556. [CrossRef]

58. Al-Halifa, S.; Gauthier, L.; Arpin, D.; Bourgault, S.; Archambault, D. Nanoparticle-Based Vaccines Against Respiratory Viruses. Front. Immunol. 2019, 10, 22. [CrossRef]

59. Hobernik, D.; Bros, M. DNA Vaccines-How Far From Clinical Use? Int. J. Mol. Sci 2018, 19, 3605. [CrossRef]

60. Nidetz, N.F.; McGee, M.C.; Tse, L.V.; Li, C.; Cong, L.; Li, Y.; Huang, W. Adeno-associated viral vector-mediated immune responses: Understanding barriers to gene delivery. Pharmacol. Ther. 2020, 207, 107453. [CrossRef] [PubMed]

61. Santos, A.F.; Gaspar, P.D.; de Souza, H.J.L. Refrigeration of COVID-19 Vaccines: Ideal Storage Characteristics, Energy Efficiency and Environmental Impacts of Various Vaccine Options. Energies 2021, 14, 1849. [CrossRef]

62. Robbins, J.B.; Schneerson, R.; Szu, S.C. Perspective: Hypothesis: Serum IgG antibody is sufficient to confer protection against infectious diseases by inactivating the inoculum. J. Infect. Dis. 1995, 171, 1387-1398. [CrossRef] [PubMed]

63. Luke, T.C.; Casadevall, A.; Watowich, S.J.; Hoffman, S.L.; Beigel, J.H.; Burgess, T.H. Hark back: Passive immunotherapy for influenza and other serious infections. Crit. Care Med. 2010, 38, e66-e73. [CrossRef] [PubMed]

64. Hung, I.F.; To, K.K.; Lee, C.K.; Lee, K.L.; Chan, K.; Yan, W.W.; Liu, R.; Watt, C.L.; Chan, W.M.; Lai, K.Y.; et al. Convalescent plasma treatment reduced mortality in patients with severe pandemic influenza A (H1N1) 2009 virus infection. Clin. Infect. Dis. 2011, 52, 447-456. [CrossRef]

65. Van Griensven, J.; De Weiggheleire, A.; Delamou, A.; Smith, P.G.; Edwards, T.; Vandekerckhove, P.; Bah, E.I.; Colebunders, R.; Herve, I.; Lazaygues, C.; et al. The Use of Ebola Convalescent Plasma to Treat Ebola Virus Disease in Resource-Constrained Settings: A Perspective From the Field. Clin. Infect. Dis. 2016, 62, 69-74. [CrossRef]

66. Rubin, R. Testing an Old Therapy Against a New Disease: Convalescent Plasma for COVID-19. JAMA 2020. [CrossRef]

67. Wang, L.T.; Ma, K.S. Correspondence to 'Normal human enthesis harbours conventional CD4+ and CD8+ T cells with regulatory features and inducible IL-17A and TNF expression'. Ann. Rheum. Dis. 2020. [CrossRef] [PubMed]

68. Rojas, M.; Rodriguez, Y.; Monsalve, D.M.; Acosta-Ampudia, Y.; Camacho, B.; Gallo, J.E.; Rojas-Villarraga, A.; Ramirez-Santana, C.; Diaz-Coronado, J.C.; Manrique, R.; et al. Convalescent plasma in Covid-19: Possible mechanisms of action. Autoimmun. Rev. 2020, 19, 102554. [CrossRef] [PubMed]

69. Coley, W.B., II. Contribution to the Knowledge of Sarcoma. Ann. Surg. 1891, 14, 199-220. [CrossRef] [PubMed]

70. Riddell, S.R.; Watanabe, K.S.; Goodrich, J.M.; Li, C.R.; Agha, M.E.; Greenberg, P.D. Restoration of viral immunity in immunodeficient humans by the adoptive transfer of T cell clones. Science 1992, 257, 238-241. [CrossRef] [PubMed]

71. Ma, K.S.; Wang, L.T.; Tsai, S.Y. Correspondence to: 'Combination of human umbilical cord mesenchymal (stromal) stem cell transplantation with IFN-gamma treatment synergistically improves the clinical outcomes of patients with rheumatoid arthritis'. Ann. Rheum. Dis. 2020. [CrossRef] [PubMed]

72. Yen, B.L.; Yen, M.L.; Wang, L.T.; Liu, K.J.; Sytwu, H.K. Current status of mesenchymal stem cell therapy for immune/inflammatory lung disorders: Gleaning insights for possible use in COVID-19. Stem Cells Transl. Med. 2020, 9, 1163-1173. [CrossRef] [PubMed]

73. Wang, L.T.; Liu, K.J.; Sytwu, H.K.; Yen, M.L.; Yen, B.L. Advances in mesenchymal stem cell therapy for immune and inflammatory diseases: Use of cell-free products and human pluripotent stem cell-derived mesenchymal stem cells. Stem Cells Transl. Med. 2021, 10, 1288-1303. [CrossRef] [PubMed]

74. Chakupurakal, G.; Onion, D.; Bonney, S.; Cobbold, M.; Mautner, V.; Moss, P. HLA-peptide multimer selection of adenovirusspecific T cells for adoptive T-cell therapy. J. Immunother. 2013, 36, 423-431. [CrossRef]

75. Ma, K.S.; Chiang, C.H.; Chen, Y.W.; Wang, L.T. Correspondence to 'Bacterial citrullinated epitopes generated by Porphyromonas gingivalis infection-a missing link for ACPA production'. Ann. Rheum. Dis. 2021. [CrossRef] [PubMed] 
76. Maus, M.V.; Thomas, A.K.; Leonard, D.G.; Allman, D.; Addya, K.; Schlienger, K.; Riley, J.L.; June, C.H. Ex vivo expansion of polyclonal and antigen-specific cytotoxic T lymphocytes by artificial APCs expressing ligands for the T-cell receptor, CD28 and 4-1BB. Nat. Biotechnol. 2002, 20, 143-148. [CrossRef] [PubMed]

77. De Alwis, R.; Chen, S.; Gan, E.S.; Ooi, E.E. Impact of immune enhancement on Covid-19 polyclonal hyperimmune globulin therapy and vaccine development. EBioMedicine 2020, 55, 102768. [CrossRef]

78. Liu, E.; Marin, D.; Banerjee, P.; Macapinlac, H.A.; Thompson, P.; Basar, R.; Nassif Kerbauy, L.; Overman, B.; Thall, P.; Kaplan, M.; et al. Use of CAR-Transduced Natural Killer Cells in CD19-Positive Lymphoid Tumors. N. Engl. J. Med. 2020, 382, 545-553. [CrossRef]

79. Hu, W.; Wang, G.; Huang, D.; Sui, M.; Xu, Y. Cancer Immunotherapy Based on Natural Killer Cells: Current Progress and New Opportunities. Front. Immunol. 2019, 10, 1205. [CrossRef] [PubMed]

80. Schwendener, R.A. Liposomes as vaccine delivery systems: A review of the recent advances. Ther. Adv. Vaccines 2014, 2, 159-182. [CrossRef]

81. McInnes, M.D.F.; Moher, D.; Thombs, B.D.; McGrath, T.A.; Bossuyt, P.M.; PRISMA-DTA Group; Clifford, T.; Cohen, J.F.; Deeks, J.J.; Gatsonis, C.; et al. Preferred Reporting Items for a Systematic Review and Meta-analysis of Diagnostic Test Accuracy Studies: The PRISMA-DTA Statement. JAMA 2018, 319, 388-396. [CrossRef] [PubMed]

82. Stroup, D.F.; Berlin, J.A.; Morton, S.C.; Olkin, I.; Williamson, G.D.; Rennie, D.; Moher, D.; Becker, B.J.; Sipe, T.A.; Thacker, S.B. Meta-analysis of observational studies in epidemiology: A proposal for reporting. Meta-analysis Of Observational Studies in Epidemiology (MOOSE) group. JAMA 2000, 283, 2008-2012. [CrossRef] [PubMed]

83. Gliklich, R.E.; Dreyer, N.A.; Leavy, M.B. Adverse Event Detection, Processing, and Reporting. Registries for Evaluating Patient Outcomes: A User's Guide, 3rd ed.; Agency for Healthcare Research and Quality: Rockville, MD, USA, 2014.

84. Principi, N.; Esposito, S. Adverse events following immunization: Real causality and myths. Expert Opin. Drug Saf. 2016, 15, 825-835. [CrossRef] [PubMed]

85. Hsu, W.T.; Esmaily-Fard, A.; Lai, C.C.; Zala, D.; Lee, S.H.; Chang, S.S.; Lee, C.C. Antipsychotics and the Risk of Cerebrovascular Accident: A Systematic Review and Meta-Analysis of Observational Studies. J. Am. Med. Dir. Assoc. 2017, 18, 692-699. [CrossRef] [PubMed] 